\title{
Influence of Hydrogen Electron Donor, Alkaline pH, and High Nitrate Concentrations on Microbial Denitrification: A Review
}

\author{
Pierre Albina ${ }^{1,2, *}$, Nadège Durban ${ }^{1,2}$, Alexandra Bertron ${ }^{1} \oplus$, Achim Albrecht ${ }^{3}$, \\ Jean-Charles Robinet ${ }^{3}$ and Benjamin Erable ${ }^{2}$ \\ 1 Laboratoire Matériaux et Durabilité des Constructions, Université de Toulouse, UPS, INSA. 135, 7 avenue de \\ Rangueil, 31077 Toulouse CEDEX 04, France; nadege.durban@gmail.com (N.D.); \\ bertron@insa-toulouse.fr (A.B.) \\ 2 Laboratoire de Génie Chimique, Université de Toulouse, CNRS, INPT, UPS, 31030 Toulouse, France; \\ benjamin.erable@ensiacet.fr \\ 3 Andra (Agence nationale pour la gestion des déchets radioactifs), 92298 Châtenay-Malabry, France; \\ achim.albrecht@andra.fr (A.A.); jean-charles.robinet@andra.fr (J.-C.R.) \\ * Correspondence: pierre.albina@ensiacet.fr
}

Received: 18 July 2019; Accepted: 15 October 2019; Published: 18 October 2019

\begin{abstract}
Bacterial respiration of nitrate is a natural process of nitrate reduction, which has been industrialized to treat anthropic nitrate pollution. This process, also known as "microbial denitrification", is widely documented from the fundamental and engineering points of view for the enhancement of the removal of nitrate in wastewater. For this purpose, experiments are generally conducted with heterotrophic microbial metabolism, neutral $\mathrm{pH}$ and moderate nitrate concentrations $(<50 \mathrm{mM})$. The present review focuses on a different approach as it aims to understand the effects of hydrogenotrophy, alkaline $\mathrm{pH}$ and high nitrate concentration on microbial denitrification. Hydrogen has a high energy content but its low solubility, $0.74 \mathrm{mM}\left(1 \mathrm{~atm}, 30^{\circ} \mathrm{C}\right)$, in aqueous medium limits its bioavailability, putting it at a kinetic disadvantage compared to more soluble organic compounds. For most bacteria, the optimal $\mathrm{pH}$ varies between 7.5 and 9.5. Outside this range, denitrification is slowed down and nitrite $\left(\mathrm{NO}_{2}{ }^{-}\right)$accumulates. Some alkaliphilic bacteria are able to express denitrifying activity at $\mathrm{pH}$ levels close to 12 thanks to specific adaptation and resistance mechanisms detailed in this manuscript, and some bacterial populations support nitrate concentrations in the range of several hundred $\mathrm{mM}$ to $1 \mathrm{M}$. A high concentration of nitrate generally leads to an accumulation of nitrite. Nitrite accumulation can inhibit bacterial activity and may be a cause of cell death.
\end{abstract}

Keywords: hydrogenotrophic denitrification; high $\mathrm{pH}$; high nitrate concentration; denitrifying bacteria; nitrite accumulation; acclimation; mineral carbon

\section{Introduction}

Microbial denitrification is considered as more efficient at high nitrate concentration and more economical compared to physico-chemical techniques for nitrate removal (reverse osmosis, ion exchange, electrodialysis, chemical denitrification, adsorption methods) [1,2]. It is a respiration process leading to the reduction of nitrate while an electron donor (organic matter, hydrogen...) is oxidized. Nitrate is gradually reduced to nitrite, nitric oxide, nitrous oxide, and finally to dinitrogen in four successive reactions catalyzed by four microbial reductases. Microbial denitrification is still insufficiently investigated in non-conventional environments such as high nitrate concentrations, alkaline $\mathrm{pH}$ and hydrogenotrophic metabolism, despite its interest in the processing of various 
problematic industrial wastes. Therefore, the aim of this literature review is to give some indications of the possibilities of bacterial denitrification under these three conditions.

Several industries generate effluent and waste that can be highly concentrated in nitrate sometimes associated with non-advantageous environments such as alkaline $\mathrm{pH}$ and absence of organic matter. The disposal of radioactive waste deep underground faces a nitrate leaching issue in an alkaline environment. High nitrate concentrations $(10 \mathrm{mM}$ to $1 \mathrm{M})$ are expected in the vicinity of the radioactive waste, which could enhance radionuclide mobility [3-5]. The effluent from a stain-less steel plant was found to contain concentrations of up to $80 \mathrm{mM}$ nitrate [6] and wastewater from the explosives industry can reach nitrate concentrations of up to $500 \mathrm{mM}$ [7]. The management of such highly concentrated nitrate waste has become a major concern for these industries. High nitrate concentrations are fairly detrimental for microbial denitrification; the maximal nitrate concentrations tested in the literature range from hundreds of $\mathrm{mM}$ [8] to $1 \mathrm{M}$ [9]. In particular, high nitrate concentrations cause nitrite accumulation, which is described as inhibiting, or even toxic, for bacteria [10-12]. Experimenting with high nitrate concentrations also requires high concentrations of the counter-ion $\mathrm{Na}^{+}, \mathrm{K}^{+}, \mathrm{Ca}^{2+}$, etc. to be added with nitrate. Caution is necessary here as there is no consensus on the effect of these cations [3].

Alkaline $\mathrm{pH}$ can be found in alkaline wastewaters [13], marsh soil management [14,15], alkaline lakes [16], and in disposal facilities for radioactive wastes. The alkaline environment strongly affects microbial denitrification. As the $\mathrm{pH}$ affects the functioning of all enzymes, it can also create an imbalance between the reduction kinetics of the four reductases of denitrification. Alkaline $\mathrm{pH}$ thus causes accumulation of metabolic intermediates such as nitrite. The maximal $\mathrm{pH}$ tolerated by bacteria, even alkaliphilic ones, is around $\mathrm{pH} 11.5$ to 12 [17].

Hydrogen is an alternative energy source replacing organic matter for denitrifying bacteria. In subsurface environments or in industrial contexts such as a radioactive waste underground repository, organic matter concentrations can be low to negligible, while hydrogen can be generated through water radiolysis, mineral reactions, or iron corrosion [18-21]. Hydrogenotrophic denitrification has also aroused interest in the field of wastewater treatment as it results in water with low organic matter content $[22,23]$. Such denitrification (without organic matter) is considered to result in slower nitrate reduction and bacterial growth kinetics than heterotrophic denitrification (with organic matter) [24,25]. This is mainly due to the low hydrogen solubility [26,27] and the necessity for hydrogenotrophic bacteria to assimilate inorganic carbon for growth [28].

\section{Definition and Biochemical Aspects of Denitrification}

Microbial denitrification is a biological respiration process involving the successive reduction of nitrogen compounds: nitrate, nitrite, nitric oxide, and nitrous oxide, to nitrogen. The four steps are catalyzed by four different enzymes (reductases) (Figure 1) [29].

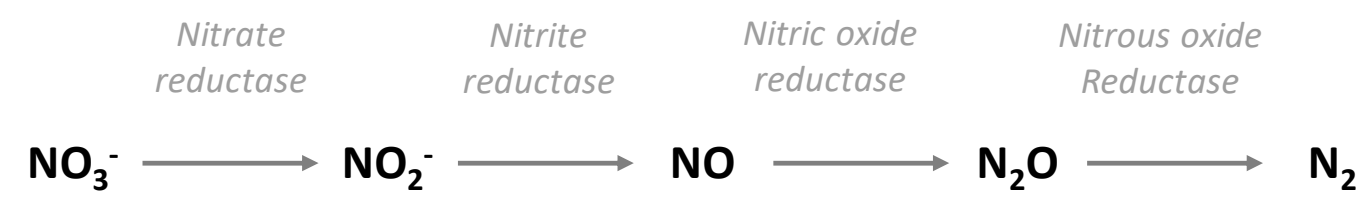

Figure 1. Overview of the four steps of microbial denitrification.

Microbial denitrification is generally carried out by heterotrophic bacteria using, for example, acetate as the electron donor (reaction (1)). When the environment is more restrictive, without organic matter, hydrogen becomes an alternative source of electrons for bacteria [23] (reaction (2)). Microbial denitrification, whether heterotrophic or hydrogenotrophic, is always accompanied by the production of $\mathrm{OH}^{-}$ions, which affect the $\mathrm{pH}$ of the environment if it is not buffered.

$$
5 \mathrm{CH}_{3} \mathrm{COOH}+8 \mathrm{NO}_{3}{ }^{-} \rightarrow 10 \mathrm{CO}_{2}+4 \mathrm{~N}_{2}+6 \mathrm{H}_{2} \mathrm{O}+8 \mathbf{O H}^{-}
$$




$$
2 \mathrm{NO}_{3}{ }^{-}+5 \mathrm{H}_{2} \rightarrow 4 \mathrm{H}_{2} \mathrm{O}+\mathrm{N}_{2}+2 \mathrm{OH}^{-}
$$

Nitrate respiration is the process in which electrons are transferred from a donor (organic matter, hydrogen) to the nitrate acceptor (Figure 2). This redox reaction along the respiratory chain cogenerates a gradient of protons through the bacterial cell membrane, which is finally converted into energy in the form of ATP by ATP synthase [30].

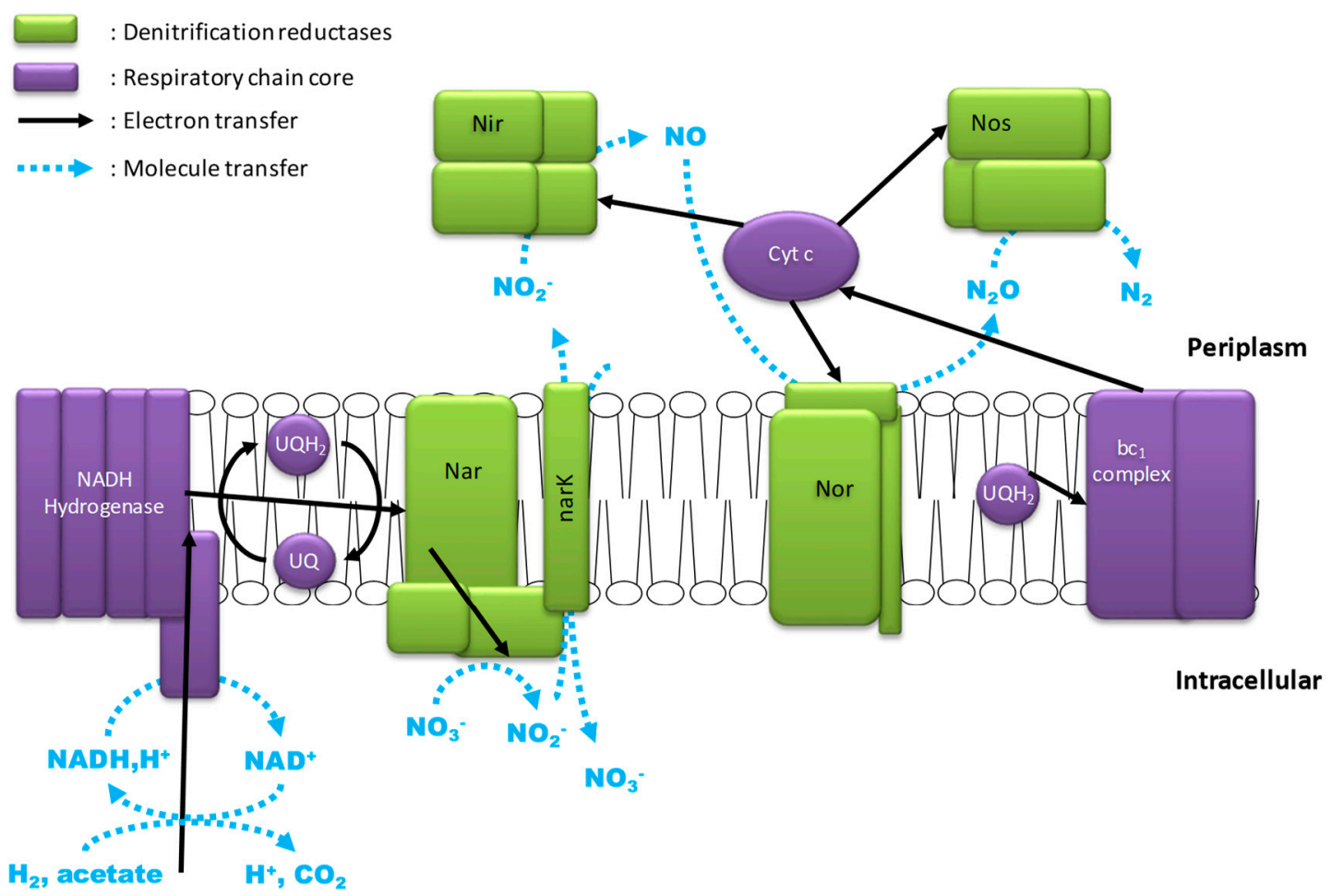

Figure 2. Schematic representation of the canonical respiratory chain of denitrification after [29-31].

Firstly, the electrons from the primary source of electrons (acetate, hydrogen, methanol, etc.) regenerate co-enzymes, such as $\mathrm{NADH}, \mathrm{H}^{+}$. $\mathrm{NADH}, \mathrm{H}^{+}$, or other potential electron donors such as succinate, which transfer their electrons to the respiratory chain [31]. Then electrons are carried through the respiratory chain by three types of electron transporters: (i) the Coenzyme $Q$ known as Ubiquinone (UQ) in its oxidized state and Ubiquinol $\left(\mathrm{UQH}_{2}\right)$ in its reduced state, (ii) the cytochrome $\mathrm{bc}_{1}$ complex, and (iii) the cytochrome c (Cyt. c) family of proteins containing a heme c [31,32]. Each of them can interact with several reductases $[29,30]$.

The first reductase is the nitrate reductase (Nar). Three types of bacterial Nar complexes have been described. The membrane complex NarGHI is a molybdoenzyme, the active site of which faces the cytoplasm. This complex is usually adjacent to the narK membrane protein; it is an $\mathrm{NO}_{3}{ }^{-} / \mathrm{NO}_{2}{ }^{-}$ antiporter that absorbs $\mathrm{NO}_{3}{ }^{-}$and excretes $\mathrm{NO}_{2}{ }^{-}$, Figure 2. The periplasmic reductase Nap reduces nitrate but cannot contribute to the proton gradient. The last nitrate reductase (Nas), is a periplasmic complex quite distinct from other reductase systems, as it is used in assimilatory nitrate reduction [33]. The nitrite produced by the nitrate reduction is then reduced by nitrite reductase (Nir). Two periplasmic types of enzymes have already been described: $\mathrm{cd}_{1}$-nitrite reductase with a heme-based active site and nitrite reductase with a copper-based active site [34]. The product of nitrite reduction, nitric oxide, is transformed by the membrane nitric oxide reductase (Nor) which is a member of the heme-copper oxidases family also capable, of reducing oxygen [35]. The last reduction is made by nitrous oxide reductase. It is a periplasmic enzyme that contains two $\mathrm{Cu}$ cores $[29,30,36]$. 


\section{Influence of High Nitrate Concentration on Denitrification}

\subsection{Regulation of Denitrification, Nitrite Accumulation}

Many denitrifying bacteria are facultative anaerobic: in the presence of oxygen the denitrification pathway is inhibited, and only aerobic respiration remains as it has the most efficient Gibbs free energy conservation. When $\mathrm{O}_{2}$ is low and $\mathrm{NO}_{3}{ }^{-}$is available, denitrification is initiated. The denitrification intermediates $\mathrm{NO}_{2}{ }^{-}$and $\mathrm{NO}$ are toxic compounds to bacterial cells [10-12,29], their internal concentration is regulated below cytotoxic levels to $\mathrm{mM}$ and $\mathrm{nM}$ respectively [30,31]. Consequently, $\mathrm{O}_{2}, \mathrm{NO}_{3}{ }^{-}, \mathrm{NO}_{2}{ }^{-}$and $\mathrm{NO}$ are among the key signals that impact denitrification regulation. The regulation of the microbial denitrification at transcriptional level has been extensively studied using model denitrifying strains such as Paraccocus denitrificans or Pseudomonas aeruginosa. In denitrifying bacteria, the regulation of denitrification reductase gene transcription is managed by transcription factors of the FNR (Fumarate and Nitrate reductase Regulatory) family [37]. For example, in P. denitrificans, three types of FNR are involved: $\mathrm{NarR}\left(\mathrm{NO}_{3}{ }^{-}\right.$and $\mathrm{NO}_{2}{ }^{-}$sensitive), $\mathrm{NnrR}$ and FnrP $\left(\mathrm{O}_{2}\right.$ and NO sensitive). Each one stimulates the transcription of different reductase genes (Figure 3).
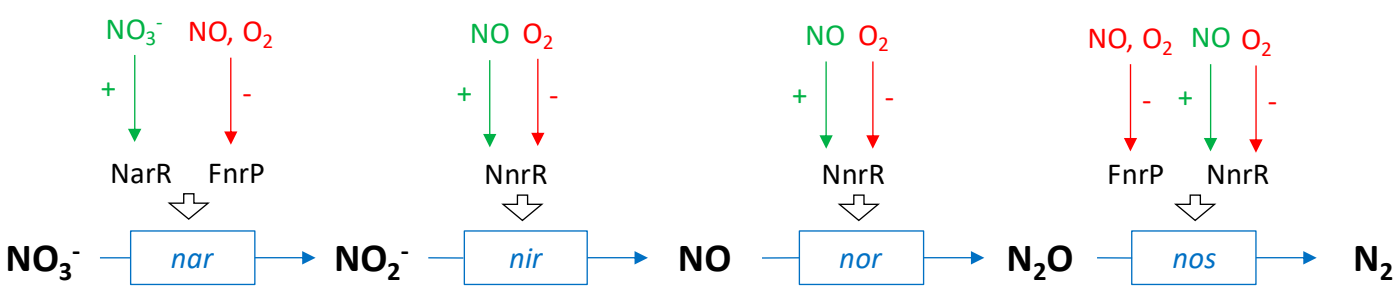

Figure 3. Schematic representation of the transcriptional regulation of the expression of genes encoding the different enzymes involved in denitrification in P. denitrificans [31,37].

In the well-studied denitrifying strain P. aeruginosa, the regulation is controlled by $\mathrm{NarXL}\left(\mathrm{NO}_{3}{ }^{-}\right.$ and $\mathrm{NO}_{2}{ }^{-}$sensitive), ANR, DNR and $\mathrm{NosR}$ ( $\mathrm{NO}$ and $\mathrm{O}_{2}$ sensitive) [38-41]. To sum up, in denitrifying bacteria, at the genomic level, there is a substrate regulation with $\mathrm{NO}_{3}{ }^{-}$and a product regulation from $\mathrm{NO}$ and $\mathrm{NO}_{2}{ }^{-}$, the aim of which is to equilibrate the internal concentration of cytotoxic compounds such as $\mathrm{NO}_{2}{ }^{-}$and $\mathrm{NO}$ [31]. Therefore, in culture under favourable conditions, intermediates as $\mathrm{NO}_{2}{ }^{-}$ and NO should not accumulate.

However, at a metabolic level, reductases competition can cause $\mathrm{NO}_{2}{ }^{-}$or $\mathrm{N}_{2} \mathrm{O}$ accumulation. In the respiratory chain the transporters $\mathrm{UQH}_{2}$ can interact with three reductases (Nar, Nir, and Nos) and the transporters Cyt c with two reductases (Nir and Nos) [42,43]. $\mathrm{UQH}_{2}$ and Cyt c are therefore solicited by several electron acceptors at the same time and depending on the environmental conditions, such as the $\mathrm{pH}$, electron transporters could transfer their electrons preferentially to one reductase rather than another $[43,44]$. Thus, at acidic $\mathrm{pH}(5.5)$, segmented denitrification was observed in $P$. denitrificans [43], i.e., the authors observed accumulation of $\mathrm{NO}_{2}{ }^{-}$and $\mathrm{N}_{2} \mathrm{O}$ because $\mathrm{UQH}_{2}$ and Cyt c transferred electrons preferentially to some reductases, while at $\mathrm{pH} \mathrm{8.5,} \mathrm{there} \mathrm{were} \mathrm{no} \mathrm{accumulations:}$ $\mathrm{UQH}_{2}$ and Cyt c transferred electrons simultaneously to all reductases. Furthermore, the electron donor also impacts nitrite accumulation depending on the number of electrons it is likely to supply. In one study, nitrite accumulation occurred when a culture of Pseudomonas stutzeri was fed with $5 \mathrm{mM}$ of acetate (two atoms of carbon) but did not occur with $5 \mathrm{mM}$ of butyrate (four atoms of carbon) [45]. Butyrate is likely to release 20 electrons during its oxidation, while acetate releases only eight electrons, so it provides sufficient electrons and avoids competition among reductases for electron acceptance. Thus, accumulation of intermediates such as nitrite could occur because of environmental conditions and despite the strict regulation of transcription. To prevent nitrite accumulation within the cell, bacteria use transporters such as narK to excrete the nitrite [46].

In a mixed bacterial population, two distinct bacterial phenotypes can affect the nitrate and nitrite equilibrium: (i) nitrate respiring bacteria unable to reduce nitrite, (ii) true denitrifying bacteria reducing 
nitrate and nitrite to dinitrogen [47-50]. Growth rates are higher for nitrate respiring bacteria, and they rapidly become dominant. For example, growth rates three times higher have been observed for nitrate respiring bacteria [51]. Consequently, in the presence of nitrate, the domination of nitrate respiring bacteria causes nitrite accumulation. Once nitrate is consumed, the true denitrifiers continue to develop using nitrite and become dominant. In one study, activated sludge was acclimatized to nitrate concentrations of $190 \mathrm{mM}$ at pH 7 to 9 in SBR reactors. The dominant bacteria in the inoculum were nitrate respiring bacteria while the bacteria remaining at the culture end were true denitrifying bacteria [47]. In this experiment, the accumulation of nitrite was $\mathrm{pH}$-dependent; increasing with higher $\mathrm{pH}$. Glass et al. hypothesized that the activity of true denitrifiers was slowed by alkaline $\mathrm{pH}$. In summary, in a culture inoculated by a mixed population, the bacterial population and the culture conditions, such as alkaline $\mathrm{pH}$, would impact nitrite accumulation. Therefore, in single strain or mixed population cultures exposed to high $\mathrm{pH}$ or high nitrate concentrations, the nitrite accumulations should not follow the same patterns.

Nitrite accumulation is problematic to denitrifying culture and in general for bacterial activity. The nitrite can inhibit and slow down bacterial activity at relatively low concentrations (tens of $\mathrm{mM}$ ) [52]. It seems that nitrite can activate the synthesis of bacteriostatic molecules in Bacillus cereus [12]. Several other bacterial metabolic pathways such as nitrification [11,53,54] or methanogenesis [55] are also sensitive to the presence of nitrite. Concentrations of $10 \mathrm{mM}$ to $100 \mathrm{mM}$ of nitrite have been described as responsible for inhibitions of $\mathrm{O}_{2}$ assimilation, proline transport, or phosphorylating oxidation [10]. Moreover, nitrite can inhibit bacterial activity at a genomic level. Concentrations of 10 to $20 \mathrm{mM}$ of nitrite caused a decrease in the concentration of mRNAs encoding for nitrification enzymes in the Nitrosospira multiformis and Nitrosospira europaea strains [11]. Other studies have reported nitrite toxicity [52] and even bacterial cell mortality in the presence of nitrite $[10,56]$. However, some bacteria could develop resistance to nitrite, for instance P. denitrificans tolerated $140 \mathrm{mM}$ of nitrite in the presence of oxygen [57]. In conclusion, nitrite accumulation could be one of the major issues when denitrifying bacteria are cultivated with high nitrate concentrations.

\subsection{High Nitrate Concentrations Reported in the Literature}

In the literature, the maximum concentrations of nitrate tested in denitrifying cultures were of the order of hundreds of $\mathrm{mM}[45,48,51,58]$. For example, an activated sludge culture was fed with an aqueous solution containing $645 \mathrm{mM}$ of nitrate [59]. Lagoon samples (Oak Ridge, USA) initially concentrated at $645 \mathrm{mM}$ of nitrate have been almost entirely denitrified (residual concentration of $0.8 \mathrm{mM}$ ) within a year [8]. Denariaz et al. [9] have reported the ability of a single strain culture of Bacillus halodenitrificans to survive at a concentration of $1.06 \mathrm{M}$ of nitrate. In another study, Rhodococcus sp. was grown on $0.9 \mathrm{M}$ of nitrate and $0.9 \mathrm{M}$ of $\mathrm{NaCl}$ in aerobiosis [60]. These studies show that bacterial activity is possible at nitrate concentrations up to molar concentration in particular conditions. However, careful attention is needed as authors usually report nitrate concentrations from the feeding medium and not from the culture medium in contact with bacteria.

When using a synthetic medium for the cultivation of denitrifying bacteria or mixed consortia, the generation of such high concentrations of nitrate requires special attention to be paid to the counter-ion $\left(\mathrm{NH}_{4}{ }^{+}, \mathrm{Na}^{+}, \mathrm{Ca}^{2+}, \mathrm{K}^{+} \ldots\right)$ added with nitrate. There is no consensus on the effect of these highly concentrated cations on bacterial growth and activities. Francis and Hatcher compared the effect of three counter-ions $\left(\mathrm{NH}_{4}{ }^{+}, \mathrm{Na}^{+}, \mathrm{Ca}^{2+}\right)$ on the denitrification kinetics of coastal sediments. Cultures underwent progressive nitrate increases up to $285 \mathrm{mM}$ [3]. For each increase in the concentration of nitrate, denitrification kinetics were significantly higher when nitrate was added in the form of $\mathrm{NH}_{4} \mathrm{NO}_{3}$. Additions of $\mathrm{NaNO}_{3}$ and $\mathrm{Ca}\left(\mathrm{NO}_{3}\right)_{2}$ resulted in lower reduction kinetics. In addition, the salinity of the culture medium also has a significant effect on denitrifying bacterial cultures. In a culture with biomass initially adapted to $410 \mathrm{mM}$ of $\mathrm{NaCl}$, the $\mathrm{NaCl}$ concentration was increased from 8 to $1700 \mathrm{mM}$ [61]. The results showed that the rate of denitrification decreased as the salt concentration increased. In contrast, some studies have reported rather high $\mathrm{NaCl}$ threshold concentrations: $1 \mathrm{M}$ [62], 
1.2 $\mathrm{M}$ [63], 1.9 M [64] and 4.25 M [9]. As an example, seawater contains $0.6 \mathrm{M}$ of $\mathrm{NaCl}$ on average. Other studies observed denitrification enhancement by adding $\mathrm{NaCl}$ from $6.8 \mathrm{mM}$ to $1.7 \mathrm{M}$ [61] or calcium up to $3.75 \mathrm{mM}[6]$.

Several studies have focused on the treatment of wastewater containing high nitrate concentrations from 100 to $1000 \mathrm{mM}$ using activated sludge [6,59,63-66]. Experiments are presented in Table 1, showing the acclimation procedure and the nitrite build-up. The acclimation procedure made it possible to adapt bacteria to high nitrate concentrations by stepwise increases. As a result, in all experiments the nitrate was totally reduced, and the distribution of bacterial communities in activated sludge changed in favour of nitrate respiring bacteria [59].

Table 1. Experiments with activated sludge cultures highly concentrated in nitrate, acclimation procedure and nitrite accumulation.

\begin{tabular}{|c|c|c|c|c|}
\hline Experimental Protocol & Acclimation Procedure & $\begin{array}{c}\text { Nitrate } \\
\text { (In Culture) }\end{array}$ & $\begin{array}{c}\text { Nitrite } \\
\text { Build-Up }\end{array}$ & Ref. \\
\hline $\begin{array}{l}\text { Ca increase from } 50 \text { to } \\
550 \mathrm{~g} / \mathrm{L} \text { at } 45 \mathrm{mM} \\
\text { nitrate, } \mathrm{pH} 8.5\end{array}$ & $\begin{array}{l}\text { Medium diluted x2 during } \\
2 \text { weeks }\end{array}$ & $45 \mathrm{mM}$ & $\max 2.5 \mathrm{mM}$ & [6] \\
\hline $\begin{array}{l}\text { Nitrate increase to } \\
580 \mathrm{mM} \text { and ionic } \\
\text { strength from } 0.8 \text { to } 3.0 \\
\text { in SBR, pH } 9\end{array}$ & $\begin{array}{l}\text { Stepwise nitrate increase } \\
\text { from } 100 \mathrm{mM} \text { to } 580 \mathrm{mM} \text { in } \\
\text { about } 6 \text { weeks }\end{array}$ & $\begin{array}{l}100 \mathrm{mM} \\
215 \mathrm{mM} \\
300 \mathrm{mM}\end{array}$ & $\begin{array}{c}70 \mathrm{mM} \\
140 \mathrm{mM} \\
240 \mathrm{mM}\end{array}$ & [63] \\
\hline $\begin{array}{l}\text { Test at } 140 \mathrm{mM} \text { nitrate } \\
\text { in a batch reactor, } \mathrm{pH} \\
9 / \text { Nitrate increase to } \\
1000 \mathrm{mM} \text { in a } \\
\text { continuous reactor }\end{array}$ & $\begin{array}{l}\text { Stepwise nitrate increase } \\
\text { Preculture: } 14 \mathrm{mM} \text { to } \\
140 \mathrm{mM} \text { in } 5 \text { weeks } \\
\text { Culture: } 140 \text { to } 1000 \mathrm{mM} \\
\quad \text { in } 14 \text { weeks }\end{array}$ & $140 \mathrm{mM}$ & $50 \mathrm{mM}^{1}$ & [65] \\
\hline $\begin{array}{l}\text { Nitrate increase to } \\
640 \mathrm{mM} \text { in SBR }\end{array}$ & $\begin{array}{c}\text { Step-wise nitrate increase } \\
\text { in the medium from } \\
120 \mathrm{mM} \text { to } 640 \mathrm{mM} \text { in } \\
8 \text { weeks }\end{array}$ & $\begin{array}{c}430 \mathrm{mM} \\
290 \mathrm{mM} \\
120 \mathrm{mM} \\
60 \mathrm{mM}\end{array}$ & $\begin{array}{c}420 \mathrm{mM} \\
290 \mathrm{mM} \\
60 \mathrm{mM} \\
0 \mathrm{mM}\end{array}$ & [59] \\
\hline $\begin{array}{l}\mathrm{NaCl} \text { stress decrease } \\
\text { from } 11 \text { to } 0 \% \text { at } \\
430 \mathrm{mM} \text {, in continuous } \\
\text { reactor }\end{array}$ & $\begin{array}{l}\text { Stepwise nitrate increase } \\
\text { from } 140 \mathrm{mM} \text { to } 430 \text { in } \\
3 \text { weeks }\end{array}$ & $430 \mathrm{mM}$ (influent) & $\begin{array}{l}\text { 70-360 mM } \\
\text { (effluent) }\end{array}$ & {$[64]$} \\
\hline $\begin{array}{l}\text { pH increase from } \\
\text { pH } 7.5 \text { to } 12 \text { in SBR }\end{array}$ & $\begin{array}{l}\text { Step-wise } \mathrm{pH} \text { increase } \\
\text { from } 7.5 \text { to } 11.5 \text { in } 8 \text { weeks }\end{array}$ & $60 \mathrm{mM}$ & $\begin{array}{l}\text { 30-55 mM } \\
\text { (high pH) }\end{array}$ & [66] \\
\hline
\end{tabular}

From Table 1 it is possible to estimate the proportion of reduced nitrite according to the initial nitrate concentration in the culture, as presented in Figure 4. Below $100 \mathrm{mM}$ nitrate, the accumulation of nitrite does not exceed $90 \%$ of the initial nitrate concentration. Between 100 and $300 \mathrm{mM}$ of nitrate, the accumulation of nitrite reaches between $40 \%$ and $70 \%$. For concentrations greater than or equal to $300 \mathrm{mM}$, nitrite is no longer reduced except in one study [63]. Therefore, when experimenting on high nitrate concentration attention must be paid to the nitrite accumulation as it could reach concentrations as high as $420 \mathrm{mM}$. However, these studies focused on nitrate reduction, and longer experimental times might have allowed true denitrifying bacteria to proliferate and reduce nitrite. 


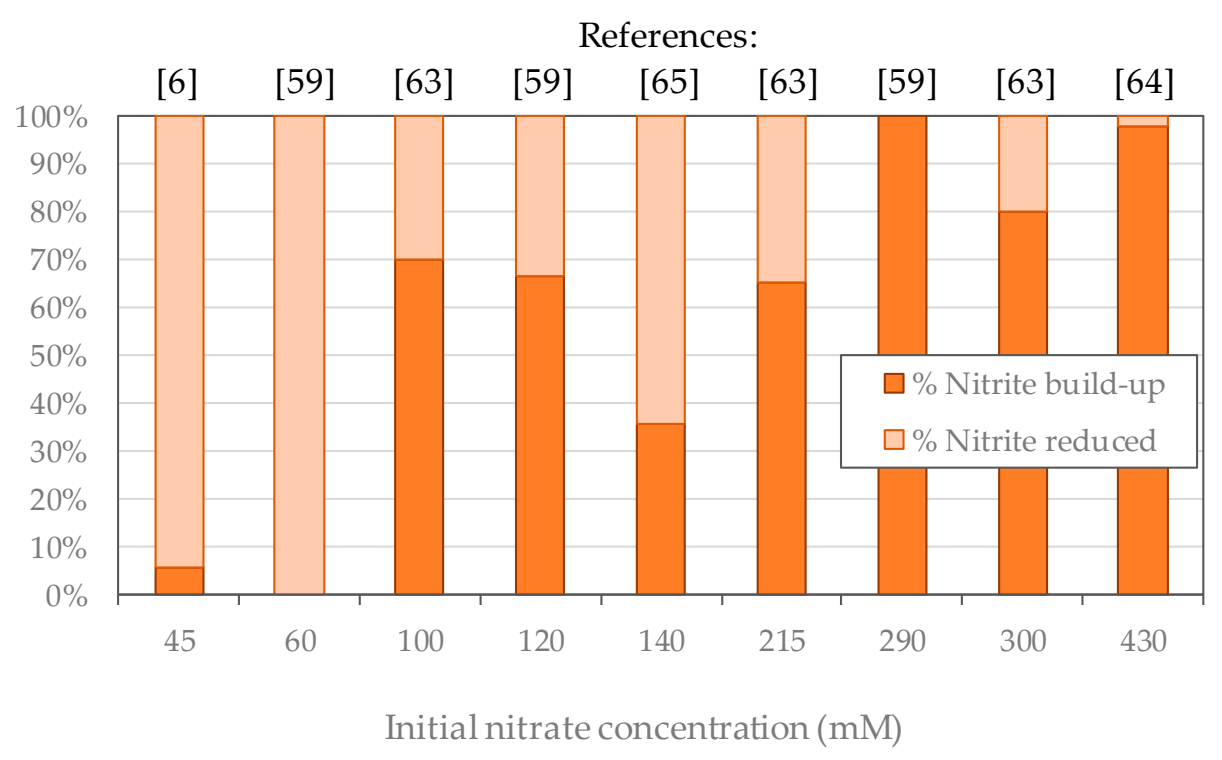

Figure 4. Proportions of nitrite reduced and accumulated according to the initial nitrate concentration in bacterial cultures after $[6,59,63-65]$.

\section{Hydrogenotrophic Metabolism and Interactions with Denitrification}

Hydrogen is an alternative energy source for denitrifying microorganisms in selective environments without organic electron donors. In order to survive in these environments, denitrifying bacteria must have the capacity to utilize nitrate as a nitrogen source, grow with inorganic carbon, utilize hydrogen as an electron donor and use nitrate as the terminal electron acceptor.

\subsection{Hydrogen Oxidation Catalyzed by Hydrogenase Enzymes}

Hydrogen can be used as an electrons donor by different communities of bacteria reducing $\mathrm{O}_{2}$, $\mathrm{NO}_{3}{ }^{-}, \mathrm{Fe}^{2+}, \mathrm{SO}_{4}{ }^{2-}$, and $\mathrm{CO}_{2}$ as final electron acceptors [19,67]. Firstly, the reversible oxidation of hydrogen into protons $\left(\mathrm{H}_{2} \leftrightarrow 2 \mathrm{H}^{+}+2 \mathrm{e}^{-}\right)$is catalyzed by bacterial hydrogenases. Then, the electrons are transferred to intermediates such as $\mathrm{NAD}^{+}$or $\mathrm{bc}_{1}$ complex, which introduce the electrons into the denitrification respiratory chain. Hydrogenases consist of a protein part and a metal core constituting the active site of the enzyme. Hydrogenases are classified in three families differentiated by their metalcore, which is composed of one iron atom, alone or associated with one nickel or iron atom: $[\mathrm{NiFe}],[\mathrm{FeFe}],[\mathrm{Fe}]$. The $[\mathrm{NiFe}]$ and $[\mathrm{FeFe}]$ hydrogenases have a similar domain organization, they are heterodimeric enzymes with an active site protected inside a large protein monomer and connected externally by a channel allowing only hydrogen to enter. The other, smaller monomer contains FeS clusters to transport electrons to the respiratory chain, Figure 5 [68-71]. The [Fe] hydrogenase contains a mononuclear metal center and is devoid of iron-sulfur clusters. It has only been identified in methanogenic Archaea [72]. The distribution of the three hydrogenase types in bacteria and archaebacteria are presented in Table 2. Hydrogen is rather uncommon in natural environments and is often associated with the absence of organic matter, high temperature, or high pressure, etc. Thus, the hydrogen source is utilized by a rather limited quantity of bacterial species. Most of the organisms studied as hydrogen-oxidizing denitrifiers belong to the phylum of Proteobacteria [23]. 


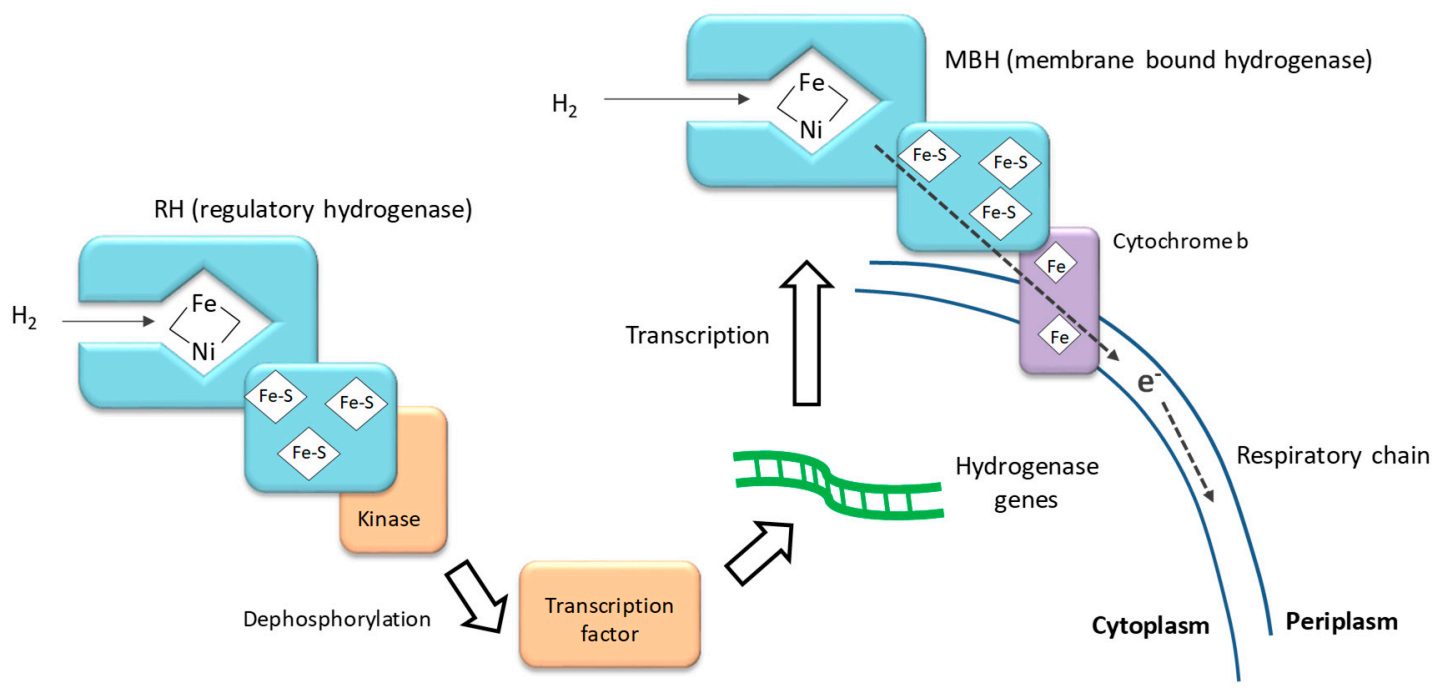

Figure 5. The regulatory [NiFe] hydrogenase and membrane-bound [NiFe] hydrogenase in Ralstonia eutropha after $[69,71]$.

Table 2. Phyla producing [NiFe], [FeFe] and [Fe] hydrogenase, with examples of strains.

\begin{tabular}{cccc}
\hline Phylum & Specie, Genus & Hydrogenase & Ref. \\
\hline Crenarchaeota (Archaea) & Thermoproteus neutrophilus & {$[\mathrm{NiFe}]$} & {$[73]$} \\
\hline Euryarchaeota (Archaea) & $\begin{array}{c}\text { Methanothermobacter marburgensis } \\
\text { Thermococcus sp. }\end{array}$ & {$[\mathrm{Fe}],[\mathrm{NiFe}]$} & {$[74]$} \\
\hline Actinobacteria & Streptomyces avermitilis & {$[\mathrm{NiFe}]$} & {$[75]$} \\
\hline Aquificae & Aquifex aeolicus & {$[\mathrm{NiFe}]$} & {$[77]$} \\
\hline Chloroflexi & Thermomicrobium roseum & {$[\mathrm{NiFe}],[\mathrm{FeFe}]$} & {$[78]$} \\
\hline Cyanobacteria & Synechocystis sp. & {$[\mathrm{NiFe}]$} & {$[79]$} \\
\hline Firmicutes & Clostridium sp. & {$[\mathrm{NiFe}],[\mathrm{FeFe}]$} & {$[80]$} \\
\hline & Paracoccus denitrificans & & {$[81,82]$} \\
& Thauera sp. & {$[83]$} \\
Proteobacteria & Hydrogenophaga sp. & {$[84,85]$} \\
& Pseudomonas stutzeri & {$[50]$} \\
& Escherichia coli & {$[86]$} \\
& Ralstonia eutropha & {$[69,87]$} \\
& Rhodopseudomonas palustris & {$[\mathrm{NiFe}],[\mathrm{FeFe}]$} & {$[89]$} \\
\hline Thermotogae & Thermotoga maritima & {$[\mathrm{FeFe}]$} & {$[90]$} \\
\hline Spirochaetes & Treponema primitia & {$[\mathrm{FeFe}]$} & \\
\hline
\end{tabular}

The regulation of hydrogenase production has been extensively studied in Ralstonia eutropha for industrial purposes [69,91,92]. In R. eutropha four [NiFe] hydrogenases have been identified: a membrane-bound hydrogenase $(\mathrm{MBH})$ linked to the respiratory chain by a cytochrome b, a cytoplasmic soluble hydrogenase ( $\mathrm{SH}$ ), an actinobacterial-type hydrogenase (not well known yet) and a regulatory hydrogenase (RH) $[87,91]$. The RH forms a tight complex with a histidine protein kinase and acts as a hydrogen sensor. In the presence of hydrogen, the RH kinase complex enhances the production of $\mathrm{MBH}$ and $\mathrm{SH}$ by phosphorylation/dephosphorylation signals transmitted to $\mathrm{MBH}$ and SH transcription factors, Figure 5 .

A similar regulation system is used by other bacteria, such as Rhodopseudomonas palustris [88]. However, many different regulatory pathways have been identified in bacteria. For instance, in Cyanobacterium Synechocystis three transcription factors regulate its hydrogenase: two positively acting regulators, LexA and AbrB1 and one repressor, AbrB2 [79]. In Escherichia coli, three transcription factors 
regulate its hydrogenase-1, ArcA and AppY enhance the hydrogenase production while IscR represses it. ArcA and AppY compete with IscR to bind with the hydrogenase gene promoter [93].

\subsection{Mineral Carbon Assimilation}

In environments devoid of organic substrates, hydrogenotrophic bacteria have to assimilate mineral carbon for growth. The enzymes involved in carbon assimilation are the carboxylases. The mineral carbon assimilation requires energy in the form of reduced co-enzyme $\left(\mathrm{NADH}, \mathrm{H}^{+}, \mathrm{FADH}, \mathrm{H}^{+}\right)$ and ATP. For instance, in the Calvin cycle, 3 ATP and $3 \mathrm{NADH}, \mathrm{H}^{+}$are consumed per equivalent of $\mathrm{CO}_{2}$ to produce glyceraldehyde-3-phosphate [94]. There are currently six known bacterial pathways leading to the assimilation of mineral carbon $[49,50,95]$ :

- $\quad$ the reductive pentose phosphate (Calvin-Benson) cycle [94]

- $\quad$ the reductive acetyl-CoA (Wood-Ljungdahl) pathway

- $\quad$ the reductive citric acid cycle, the 3-hydroxypropionate bicycle

- $\quad$ the dicarboxylate/4-hydroxybutyrate cycle

- $\quad$ the 3-hydroxypropionate/ 4-hydroxybutyrate cycle.

Carboxylases are able to assimilate mineral carbon as $\mathrm{CO}_{2}$ or $\mathrm{HCO}_{3}{ }^{-}$. The availability of these forms is dependent on the $\mathrm{pH}$, as $\mathrm{CO}_{2}$ can hydrate itself into carbonate species $\left(\mathrm{H}_{2} \mathrm{CO}_{3}, \mathrm{HCO}_{3}{ }^{-}\right.$and $\left.\mathrm{CO}_{3}{ }^{2-}\right)$ according to the $\mathrm{pH}$. This hydration $\left(\mathrm{H}_{2} \mathrm{O}+\mathrm{CO}_{2} \leftrightarrow \mathrm{H}_{2} \mathrm{CO}_{3} \leftrightarrow \mathrm{HCO}_{3}{ }^{-}+\mathrm{H}^{+} \leftrightarrow \mathrm{CO}_{3}{ }^{-}+2 \mathrm{H}^{+}\right)$ causes acidification. Most bacterial carboxylases assimilate the $\mathrm{CO}_{2}$ form. However, at $\mathrm{pH}$ between 6.4 (pKa of $\left(\mathrm{H}_{2} \mathrm{CO}_{3} / \mathrm{HCO}_{3}{ }^{-}\right)$) and 10.3 (pKa of $\left(\mathrm{HCO}_{3}{ }^{-} / \mathrm{CO}_{3}{ }^{2-}\right)$ ), the $\mathrm{HCO}_{3}{ }^{-}$form is dominant in solution. Bacteria have adapted by using carbonic anhydrases to catalyze the formation of $\mathrm{CO}_{2}$ from $\mathrm{HCO}_{3}{ }^{-}$[96], or by using several carboxylases capable of fixing the $\mathrm{HCO}_{3}{ }^{-}$form $[97,98]$.

Mineral carbon can be supplied in aqueous solution either by bubbling $\mathrm{CO}_{2}(\mathrm{~g})$ or by adding soluble carbonates $\left(\mathrm{H}_{2} \mathrm{CO}_{3}, \mathrm{HCO}_{3}{ }^{-}, \mathrm{CO}_{3}{ }^{2-}\right)$. The continuous supply of $\mathrm{CO}_{2}(\mathrm{~g})$ rapidly acidifies the $\mathrm{pH}$ of bacterial culture media [99]. In contrast, the addition of soluble carbonate buffers the solution. A study reported faster bacterial adaptation to hydrogenotrophy using $\mathrm{HCO}_{3}{ }^{-}$as carbon source rather than $\mathrm{CO}_{2}(\mathrm{~g})$ [100]. In addition, the mineral carbon supply must be balanced with a nitrogen supply in order to have an optimal carbon/nitrogen ratio for bacterial growth. In theory, $0.2 \mathrm{mg} \mathrm{HCO}_{3}{ }^{-}-\mathrm{C} / \mathrm{mg}$ $\mathrm{NO}_{3}{ }^{-} \mathrm{N}$ would be required [23]. In practice, higher $\mathrm{C} / \mathrm{N}$ mass ratios have been used in order to prevent carbon limitation [28]. Ratios should be chosen with care; $\mathrm{C} / \mathrm{N}$ ratios that are too high can lead to alternative nitrate reduction pathways, such as nitrate reduction to ammonium, while $\mathrm{C} / \mathrm{N}$ ratios that are too low lead to the inhibition of denitrification [23].

\subsection{Comparison between hydrogenotrophic and heterotrophic denitrification}

Interest in hydrogenotrophic denitrification for wastewater treatment has grown in recent decades, due to its low production of sludge $[22,23,101]$. In hydrogenotrophic cultures, denitrification and growth rate are lower than in heterotrophic cultures. In batch cultures of activated sludge, an initial concentration of $14 \mathrm{mM}$ nitrate was reduced at $2.1 \mathrm{mM} / \mathrm{d}$ in heterotrophy and at $1.3 \mathrm{mM} / \mathrm{d}$ in hydrogenotrophy [25]. This difference can be explained by the additional energy expended for mineral carbon assimilation compared to organic carbon assimilation or the kinetic disadvantage of using hydrogen with low solubility. The aqueous solubility of hydrogen is $0.74 \mathrm{mM}$ at $30^{\circ} \mathrm{C}$, thus hydrogen bioavailability can be limiting in fast biological processes [26]. In order to prevent hydrogen limitation, reactor designs have been optimized using porous membrane, hollow fiber, and silicone tube reactors [23]. These reactors are designed to improve the supply of hydrogen to bacterial cells. Thus, they result in better denitrification kinetics than simple batch reactors. In addition, based on Henry's law, the utilization of high hydrogen pressure makes it possible to increase the hydrogen solubility. To illustrate this beneficial effect, using a continuous reactor fed with $1 \mathrm{mM}$ nitrate, the nitrate reduction rates were respectively 43 and $170 \mathrm{mM} / \mathrm{d}$ at $\mathrm{P}_{\mathrm{H} 2}=0.4$ bar $(1.5$ bar total $)$ and at $\mathrm{P}_{\mathrm{H} 2}=1.3$ bar $(3 \mathrm{bar}$ total) [102]. In conclusion, hydrogenotrophic bacterial cultures often result in lower denitrification 
kinetics than in heterotrophic cultures $[22,24]$. However, in some studies, the optimization of hydrogen transfer to bacterial cells has made it possible to obtain denitrification kinetics comparable to those of heterotrophic denitrification [102-104]. An overview of the nitrate reduction rate observed in the literature according to the $\mathrm{pH}$ and the nitrate concentration is presented in Table 3. Concentrations from 0.1 to $40 \mathrm{mM}$ and $\mathrm{pH}$ from 6.5 to 9.5 have been explored. The maximal nitrate reduction rate did not exceed an order of magnitude of $100 \mathrm{mM} / \mathrm{d}$, except for the experiment with high hydrogen pressure and very low nitrate concentration [102].

Table 3. Overview of nitrate maximal reduction rates in hydrogenotrophic cultures testing different $\mathrm{pH}$ and nitrate concentrations ranges.

\begin{tabular}{|c|c|c|c|c|c|}
\hline Inoculum & $\begin{array}{l}\text { Experimental } \\
\text { Set-Up }\end{array}$ & $\mathrm{pH}$ & $\begin{array}{c}\text { Nitrate } \\
\text { mM }\end{array}$ & $\begin{array}{c}\text { Nitrate Maximal } \\
\text { Reduction Rate }\end{array}$ & Ref. \\
\hline $\begin{array}{l}\text { Activated } \\
\text { sludge }\end{array}$ & $\begin{array}{l}\text { Continuous reactor, } \\
\text { heterotrophy or } \\
\text { hydrogenotrophy }\end{array}$ & $6.5-8.7$ & $0.8-2.3$ & ND & [105] \\
\hline Consortium & $\begin{array}{l}\text { Pressured Batch } \\
\text { reactor }\end{array}$ & 7.1 & $0.07-0.7$ & $356.4 \mathrm{mM} / \mathrm{d}$ & [102] \\
\hline $\begin{array}{l}\text { Alcaligenes } \\
\text { eutrophus }\end{array}$ & $\begin{array}{l}\text { Continuous and } \\
\text { batch reactors }\end{array}$ & $7.1-9$ & $1.8-3.2$ & $50.0 \mathrm{mM} / \mathrm{d}$ & [27] \\
\hline $\begin{array}{l}\text { Paraccocus } \\
\text { denitrificans }\end{array}$ & Semi-batch reactors & $6.5-9.5$ & 40 & $8.4 \mathrm{mM} / \mathrm{gDW} / \mathrm{d}^{1}$ & [106] \\
\hline $\begin{array}{l}\text { Activated } \\
\text { sludge }\end{array}$ & Batch reactors & $6.4-7$ & $0.5-14.3$ & $5.5 \mathrm{mM} / \mathrm{d}$ & [104] \\
\hline $\begin{array}{l}\text { Activated } \\
\text { sludge }\end{array}$ & $\begin{array}{c}\text { Batch and } \\
\text { continuous reactors }\end{array}$ & ND & 14 & $1.3 \mathrm{mM} / \mathrm{d}$ & [25] \\
\hline $\begin{array}{l}\text { Activated } \\
\text { sludge }\end{array}$ & Continuous reactor & 7-9.5 & 1 & $31 \mathrm{mM} / \mathrm{d}$ & [107] \\
\hline $\begin{array}{l}\text { Activated } \\
\text { sludge }\end{array}$ & $\begin{array}{l}\text { Sequencing batch } \\
\text { reactors }\end{array}$ & $7-9.5$ & 1.4 & $27.4 \mathrm{mM} / \mathrm{d}$ & [101] \\
\hline
\end{tabular}

\section{Influence of High pH on Denitrification}

\subsection{Basics of $p H$ Effect on Denitrification}

The $\mathrm{pH}$ impacts all enzymes that work properly at an optimal $\mathrm{pH}$. In consequence, the majority of neutrophilic denitrifying bacteria have an optimal pH ranging between 7.5 and 9.5 [47,104,106,108]. At a lower $\mathrm{pH}$, denitrification activity is slowed down. In the denitrification process, reductases or electron transporters are affected by the $\mathrm{pH}$. Under the influence of the $\mathrm{pH}$, electron transporters may preferentially give their electrons to specific reductases. For example, a study was carried out to measure nitrite reductase activity and nitrous oxide reductase activity according to $\mathrm{pH}$ variation from 6.4 to 9.2 [44]. Cytochrome $\mathrm{c}$ was more oxidized by nitrite reductase than by nitrous oxide reductase at $\mathrm{pH}<7.3$ and vice versa at $\mathrm{pH}>7.3$ [44]. Besides the acidic $\mathrm{pH}$ impact on the enzymes, the bacterial activity could be slowed by the formation of nitrous acid $\left(\mathrm{HNO}_{2}\right)$ from nitrite. Nitrous acid is a cytotoxic compound that can easily cross bacterial membranes [57].

For $\mathrm{pH}$ values above the classical optimal $\mathrm{pH}$ range of 7.5 to 9.5, the denitrification kinetics recorded in the literature are generally slower and nitrite accumulations have often been observed [104,105]. In addition, the alkalinization of microbiological culture media is accompanied by an increase in the occurrence of precipitates. Denitrifying tests were performed for $\mathrm{pH}$ values from 7.7 to 9.5 [107]. At $\mathrm{pH} 9.5$, in the presence of soluble carbonates, the increasing $\mathrm{pH}$ led to the precipitation of calcium carbonates, thereby modifying the bioavailability of carbonate and $\mathrm{Ca}^{2+}$ ions in the solution. Other precipitates $\left(\mathrm{CaHPO}_{4}, \mathrm{Ca}\left(\mathrm{H}_{2} \mathrm{PO}_{4}\right)_{2}, \mathrm{Ca}_{3}\left(\mathrm{PO}_{4}\right)_{2}\right.$, etc.) are likely to form depending on the $\mathrm{pH}$ and 
the nutrients that may be added [105]. All these precipitation phenomena could limit the nutrients available for proper bacterial denitrification.

On the other hand, bacterial denitrification has an effect on $\mathrm{pH}$. The reactions below describe the reduction from nitrate to nitrite ((3) and (4)), then nitrite to nitric oxide ((5) and (6)), then nitric oxide to dinitrogen $((7)$ and $(8))$ with acetate or hydrogen. The nitrite reduction to nitric oxide ((5) and (6)) is the only reduction step that produces $\mathrm{OH}^{-}$with either acetate or hydrogen [105]. Therefore, at alkaline $\mathrm{pH}$, stopping the nitrite reduction would be a way for bacteria to avoid further $\mathrm{pH}$ increases. This would provide an explanation for the many observations of nitrite accumulations in denitrifying cultures performed in alkaline media.

$$
\begin{gathered}
4 \mathrm{H}_{2}+4 \mathrm{NO}_{3}{ }^{-} \rightarrow 4 \mathrm{NO}_{2}{ }^{-}+4 \mathrm{H}_{2} \mathrm{O} \\
\mathrm{CH}_{3} \mathrm{COOH}+4 \mathrm{NO}_{3}{ }^{-} \rightarrow 2 \mathrm{CO}_{2}+4 \mathrm{NO}_{2}{ }^{-}+2 \mathrm{H}_{2} \mathrm{O} \\
4 \mathrm{H}_{2}+8 \mathrm{NO}_{2}^{-} \rightarrow 8 \mathrm{NO}+8 \mathrm{OH}^{-} \\
\mathrm{CH}_{3} \mathrm{COOH}+8 \mathrm{NO}_{2}^{-}+2 \mathrm{H}_{2} \mathrm{O} \rightarrow 2 \mathrm{CO}_{2}+16 \mathrm{NO}+8 \mathrm{OH}^{-} \\
4 \mathrm{H}_{2}+4 \mathrm{NO} \rightarrow 2 \mathrm{~N}_{2}+4 \mathrm{H}_{2} \mathrm{O} \\
\mathrm{CH}_{3} \mathrm{COOH}+4 \mathrm{NO} \rightarrow 2 \mathrm{CO}_{2}+2 \mathrm{~N}_{2}+2 \mathrm{H}_{2} \mathrm{O}
\end{gathered}
$$

However, in heterotrophic denitrification, organic matter (such as acetate) is oxidized to $\mathrm{CO}_{2}$, which has an acidifying action and could compensate for $\mathrm{OH}^{-}$alkalinization. Therefore, calculations of $\mathrm{pH}$ were made to understand the $\mathrm{pH}$ evolution in heterotrophic cultures supplemented with acetate and a carbonate buffer. In the $\mathrm{pH}$ range of 8 to 14 , considering that all the strong base $\mathrm{OH}^{-}$reacts with $\mathrm{CO}_{2}$ to produce $\mathrm{HCO}_{3}{ }^{-}$and then with $\mathrm{HCO}_{3}{ }^{-}$to produce $\mathrm{CO}_{3}{ }^{2-}$, equation (1) can be rewritten by introducing equation (9).

$$
5 \mathrm{CH}_{3} \mathrm{COOH}+8 \mathrm{NO}_{3}{ }^{-} \rightarrow 7 \mathrm{HCO}_{3}{ }^{-}+3 \mathrm{CO}_{3}{ }^{2-}+4 \mathrm{~N}_{2}+4 \mathrm{H}_{2} \mathrm{O}
$$

\begin{tabular}{|c|c|}
\hline Equivalents & $\begin{array}{r}{\left[\mathrm{HCO}_{3}{ }^{-}\right]_{\text {produced }} \Leftrightarrow 7 / 8\left[\mathrm{NO}_{3}^{-}\right]_{\text {reduced }}} \\
{\left[\mathrm{NO}_{3}^{-}\right]_{\text {reduced }}}\end{array}$ \\
\hline Final carbonate concentrations & $\begin{array}{c}{\left[\mathrm{CO}_{3}{ }^{2-}\right]_{\text {final }}=\left[\mathrm{CO}_{3}{ }^{2-}\right]_{\text {initial }}+\left[\mathrm{CO}_{3}{ }^{2-}\right]_{\text {produced }}=\left[\mathrm{CO}_{3}{ }^{2-}\right]_{\text {initial }}+3 / 8} \\
{\left[\mathrm{NO}_{3}{ }^{-}\right]_{\text {reduced }}\left[\mathrm{HCO}_{3}{ }^{-}\right]_{\text {final }}=\left[\mathrm{HCO}_{3}\right]_{\text {initial }}+\left[\mathrm{HCO}_{3}{ }^{-}\right]_{\text {produced }}=} \\
{\left[\mathrm{HCO}_{3}{ }^{-}\right]_{\text {initial }}+7 / 8\left[\mathrm{NO}_{3}{ }^{-}\right]_{\text {reduced }}}\end{array}$ \\
\hline Henderson-Hasselbalch equation & $\mathrm{pH}=10.32+\log \left(\frac{\left[\mathrm{CO}_{3}^{2-}\right]_{\text {final }}}{\left[\mathrm{HCO}_{3}^{-}\right]_{\text {final }}}\right)$ \\
\hline Final equation & $\mathrm{pH}=10.32+\log \left(\frac{\left[\mathrm{CO}_{3}^{2-}\right]_{\text {initial }}+\frac{3}{8}\left[\mathrm{NO}_{3}^{-}\right]_{\text {reduced }}}{\left[\mathrm{HCO}_{3}^{-}\right]_{\text {initial }}+\frac{7}{8}\left[\mathrm{NO}_{3}^{-}\right]_{\text {reduced }}}\right)$ \\
\hline
\end{tabular}

Therefore, the $\mathrm{pH}$ can be calculated from the Henderson-Hasselbalch equation by determining the final concentration of $\mathrm{HCO}_{3}{ }^{-}$and $\mathrm{CO}_{3}{ }^{2-}$ depending on the nitrate reduced, Table 4 .

Table 4. Calculation of $\mathrm{pH}$ in a culture buffered with carbonate and fed with acetate according to the reduced nitrate concentration.

Therefore, the $\mathrm{pH}$ can be expressed as in equation (10). If the nitrate concentration is significantly higher than the initial carbonate concentration, the $\mathrm{pH}$ tends to $10(=10.32+\log (3 / 7))$. Therefore, during the denitrification with acetate, the $\mathrm{pH}$ may acidify or alkalinize depending on whether the 
initial $\mathrm{pH}$ is higher or lower than 10 . This pattern is reported in the literature as "self-acidification" at alkaline $\mathrm{pH}[23,57,104]$ and "self-alkalinization" at acidic $\mathrm{pH}[58,109]$.

$$
\mathrm{pH}=10.32+\mathrm{Log}\left(\frac{\left[\mathrm{CO}_{3}^{2-}\right]_{\mathrm{i}}+\frac{3}{8} \times\left[\mathrm{NO}_{3}^{-}\right]}{\left[\mathrm{HCO}_{3}^{-}\right]_{\mathrm{i}}+\frac{7}{8} \times\left[\mathrm{NO}_{3}^{-}\right]}\right)
$$

In the case of hydrogenotrophic denitrification, there is no $\mathrm{CO}_{2}$ production. The $\mathrm{pH}$ can only increase due to the production of $\mathrm{OH}^{-}$, which can react with $\mathrm{HCO}_{3}{ }^{-}$to form $\mathrm{CO}_{3}{ }^{2-}$. Therefore, the $\mathrm{pH}$ from a hydrogenotrophic culture buffered with carbonate can be calculated from equation (2) and the Henderson-Hasselbalch equation, Table 5.

Table 5. Calculation of $\mathrm{pH}$ in culture buffered with carbonate and fed with hydrogen according to the reduced nitrate concentration.

\begin{tabular}{|c|c|}
\hline Equivalents & $\begin{aligned} {\left[\mathrm{HCO}_{3}{ }^{-}\right]_{\text {consumed }} } & \Leftrightarrow\left[\mathrm{OH}^{-}\right]_{\text {produced }} \Leftrightarrow\left[\mathrm{NO}_{3}{ }^{-}\right]_{\text {reduced }} \\
{\left[\mathrm{CO}_{3}{ }^{2-}\right]_{\text {produced }} } & \Leftrightarrow\left[\mathrm{OH}^{-}\right]_{\text {produced }} \Leftrightarrow\left[\mathrm{NO}_{3}{ }^{-}\right]_{\text {reduced }}\end{aligned}$ \\
\hline Final carbonate concentrations & $\begin{array}{c}{\left[\mathrm{CO}_{3}{ }^{2-}\right]_{\text {final }}=\left[\mathrm{CO}_{3}{ }^{2-}\right]_{\text {initial }}+\left[\mathrm{CO}_{3}{ }^{2-}\right]_{\text {produced }}=\left[\mathrm{CO}_{3}{ }^{2-}\right]_{\text {initial }}+} \\
{\left[\mathrm{NO}_{3}{ }^{-}\right]_{\text {reduced }}} \\
{\left[\mathrm{HCO}_{3}{ }^{-}\right]_{\text {final }}=\left[\mathrm{HCO}_{3}{ }^{-}\right]_{\text {initial }}-\left[\mathrm{HCO}_{3}{ }^{-}\right]_{\text {consumed }}=\left[\mathrm{HCO}_{3}{ }^{-}\right]_{\text {initial }}-} \\
{\left[\mathrm{NO}_{3}{ }^{-}\right]_{\text {reduced }}}\end{array}$ \\
\hline Henderson-Hasselbalch equation & $\mathrm{pH}=10.32+\log \left(\frac{\left[\mathrm{CO}_{3}^{2-}\right]_{\text {final }}}{\left[\mathrm{HCO}_{3}^{-}\right]_{\text {final }}}\right)$ \\
\hline Final equation ${ }^{1}$ & $\mathrm{pH}=10.32+\log \left(\frac{\left[\mathrm{CO}_{3}^{2-}\right]_{\text {initial }}+\left[\mathrm{NO}_{3}^{-}\right]_{\text {reduced }}}{\left[\mathrm{HCO}_{3}^{-}\right]_{\text {initial }}\left[\mathrm{NO}_{3}^{-}\right]_{\text {reduced }}}\right)$ \\
\hline
\end{tabular}

${ }^{1}$ : does not apply if $\left[\mathrm{HCO}_{3}{ }^{-}\right]_{\text {initial }}<\left[\mathrm{NO}_{3}{ }^{-}\right]_{\text {reduced }}$, in this case, the $\mathrm{pH}$ is directly calculated from $\left[\mathrm{OH}^{-}\right]$.

During hydrogenotrophic denitrification, as expressed in equation (11), the $\mathrm{pH}$ increases regardless of the initial $\mathrm{pH}$. Moreover, the $\mathrm{pH}$ could also increase during mineral carbon assimilation. When hydrogenotrophic bacteria assimilate $\mathrm{CO}_{2}$ and $\mathrm{HCO}_{3}{ }^{-}$for growth, the carbonate equilibrium is affected and the $\mathrm{pH}$ increases.

$$
\mathrm{pH}=10.32+\log \left(\frac{\left[\mathrm{CO}_{3}^{2-}\right]_{i}+\left[\mathrm{NO}_{3}^{-}\right]}{\left[\mathrm{HCO}_{3}^{-}\right]_{i}-\left[\mathrm{NO}_{3}^{-}\right]}\right)
$$

In conclusion, in hydrogenotrophic cultures, the $\mathrm{pH}$ would increase during the denitrification and during the mineral carbon assimilation. Consequently, hydrogenotrophic bacteria without any means of acidifying the $\mathrm{pH}$ are more sensitive to alkaline $\mathrm{pH}$ than heterotrophic bacteria, which are able to acidify $\mathrm{pH}$ above 10 in the presence of acetate.

An overview of the nitrate reduction rate observed in the literature in heterotrophic cultures is presented in Table 6. Concentrations from 10 to $1000 \mathrm{mM}$ and $\mathrm{pH}$ from 5.5 to 12 are explored. The maximal nitrate reduction rate was an order of magnitude of 10 to $1000 \mathrm{mM} / \mathrm{d}$. Higher ranges of $\mathrm{pH}$ and nitrate concentration were explored in heterotrophy than in hydrogenotrophy (see Table 3). The nitrate reduction rates, up to $5000 \mathrm{mM} / \mathrm{d}$, were also higher in heterotrophy. 
Table 6. Overview of nitrate maximal reduction rates in heterotrophic cultures testing different $\mathrm{pH}$ and nitrate concentrations ranges.

\begin{tabular}{|c|c|c|c|c|c|}
\hline Inoculum & $\begin{array}{l}\text { Experimental } \\
\text { Set-Up }\end{array}$ & $\mathrm{pH}$ & $\begin{array}{l}\text { Nitrate } \\
\mathrm{mM}\end{array}$ & $\begin{array}{l}\text { Nitrate Maximal } \\
\text { Reduction Rate }\end{array}$ & Ref. \\
\hline P. denitrificans & Batch reactor & ND & 17 & $36 \mathrm{mM} / \mathrm{d}$ & [110] \\
\hline P. denitrificans & $\begin{array}{c}\text { Batch reactor, } \\
\text { an/aerobic transition }\end{array}$ & $5.5-9.5$ & 25 & $60 \mathrm{mM} / \mathrm{d}$ & [43] \\
\hline P. denitrificans & $\begin{array}{l}\text { Batch reactor, high } \\
\text { cell density }\end{array}$ & $6.4-9.2$ & 25 & $4887 \mathrm{mM} / \mathrm{d}$ & [44] \\
\hline P. denitrificans & $\begin{array}{l}\text { Continuous reactor } \\
\text { an/aerobic transition }\end{array}$ & $6.8-7.5$ & 25 & $6 \mathrm{mM} / \mathrm{d}$ & [58] \\
\hline $\begin{array}{l}\text { Activated } \\
\text { sludge }\end{array}$ & $\begin{array}{l}\text { Sequencing batch } \\
\text { reactors }\end{array}$ & $6.5-9$ & 192 & $600 \mathrm{mM} / \mathrm{d}$ & [47] \\
\hline $\begin{array}{l}\text { Activated } \\
\text { sludge }\end{array}$ & Batch reactor & $10-12$ & 15 & $2 \mathrm{mM} / \mathrm{d}$ & [54] \\
\hline $\begin{array}{l}\text { Activated } \\
\text { sludge }\end{array}$ & $\begin{array}{l}\text { Sequencing batch } \\
\text { reactors }\end{array}$ & 7.2 & $120-645$ & $1710 \mathrm{mM} / \mathrm{d}$ & [59] \\
\hline $\begin{array}{l}\text { Activated } \\
\text { sludge }\end{array}$ & $\begin{array}{l}\text { Sequencing batch } \\
\text { reactors }\end{array}$ & $7.5-12$ & 120 & $1177 \mathrm{mM} / \mathrm{d}$ & [66] \\
\hline $\begin{array}{l}\text { Activated } \\
\text { sludge }\end{array}$ & $\begin{array}{c}\text { Sequencing batch } \\
\text { reactors }\end{array}$ & $7.5-9$ & $192-580$ & $564 \mathrm{mM} / \mathrm{d}$ & [63] \\
\hline $\begin{array}{c}\text { Bacillus } \\
\text { halodenitrificans }\end{array}$ & Batch reactor & $7.5-9$ & 1006 & ND & [9] \\
\hline $\begin{array}{l}\text { Activated } \\
\text { sludge }\end{array}$ & $\begin{array}{l}\text { Sequencing batch } \\
\text { reactors }\end{array}$ & 8.5 & 42 & $137 \mathrm{mM} / \mathrm{d}$ & [6] \\
\hline $\begin{array}{l}\text { Activated } \\
\text { sludge }\end{array}$ & $\begin{array}{l}\text { Expanded granular } \\
\text { sludge bed }\end{array}$ & $6-8$ & $142-1000$ & $\begin{array}{l}99.9 \% \text { removal } \\
\text { efficiency }\end{array}$ & [65] \\
\hline
\end{tabular}

\subsection{Bacterial Adaptations to Alkaline $\mathrm{pH}$}

Most bacterial processes are significantly slowed down in an alkaline medium. However, some bacteria described as alkaliphilic grow optimally at $\mathrm{pH}$ above 9 [111]. Alkaliphilic bacteria such as Bacillus sp. were isolated from alkaline ecological niches [112] and have been extensively studied recently for industrial purposes [113,114]. Several protective mechanisms that allow alkaliphilic bacteria to maintain their metabolic activity at high $\mathrm{pH}$ can be illustrated by the example of the genus Bacillus $s p$. These mechanisms seek to keep the internal $\mathrm{pH}$ of the cells as low as possible and to adapt the internal enzymatic activity to high $\mathrm{pH}$ levels [115,116] (Figure 6).

In Bacillus $s p$. the first protective barrier, the bacterial wall, has additional acidic polymers and peptidoglycans installing a selective permeability to $\mathrm{Na}^{+}$and $\mathrm{H}^{+}$while blocking $\mathrm{OH}^{-}$anions $[115,116]$. Then, on the bacterial membrane, transporters ensure that the $\mathrm{pH}$ in the cytoplasm is maintained as low as possible by a constant flow of protons inwards. In alkaliphilic bacteria, there are several types of membrane transporters allowing protons to be absorbed: $\mathrm{Na} / \mathrm{H}$ anti-transporters, $\mathrm{K} / \mathrm{H}$ anti-transporters, and the $\mathrm{Mrp}(\mathrm{Na} / \mathrm{H})$ anti-transporter [117]. The Mrp anti-transporter is a super enzymatic complex encoded by several genes [117]. It has a crucial role in the absorption of protons and has been identified in several alkaliphilic bacterial strains [111,117]. These cellular mechanisms of protection would only generate a maximum difference of about $2 \mathrm{pH}$ units between the cytoplasm and the culture medium $[17,115]$. Sturr et al. showed that the internal $\mathrm{pH}$ of B. pseudofirmus was maintained to 8.3 when the external $\mathrm{pH}$ was 10.8 [118]. However, this bacterium was no longer able to regulate its intracellular $\mathrm{pH}$ for external $\mathrm{pH}$ above 11.4. 


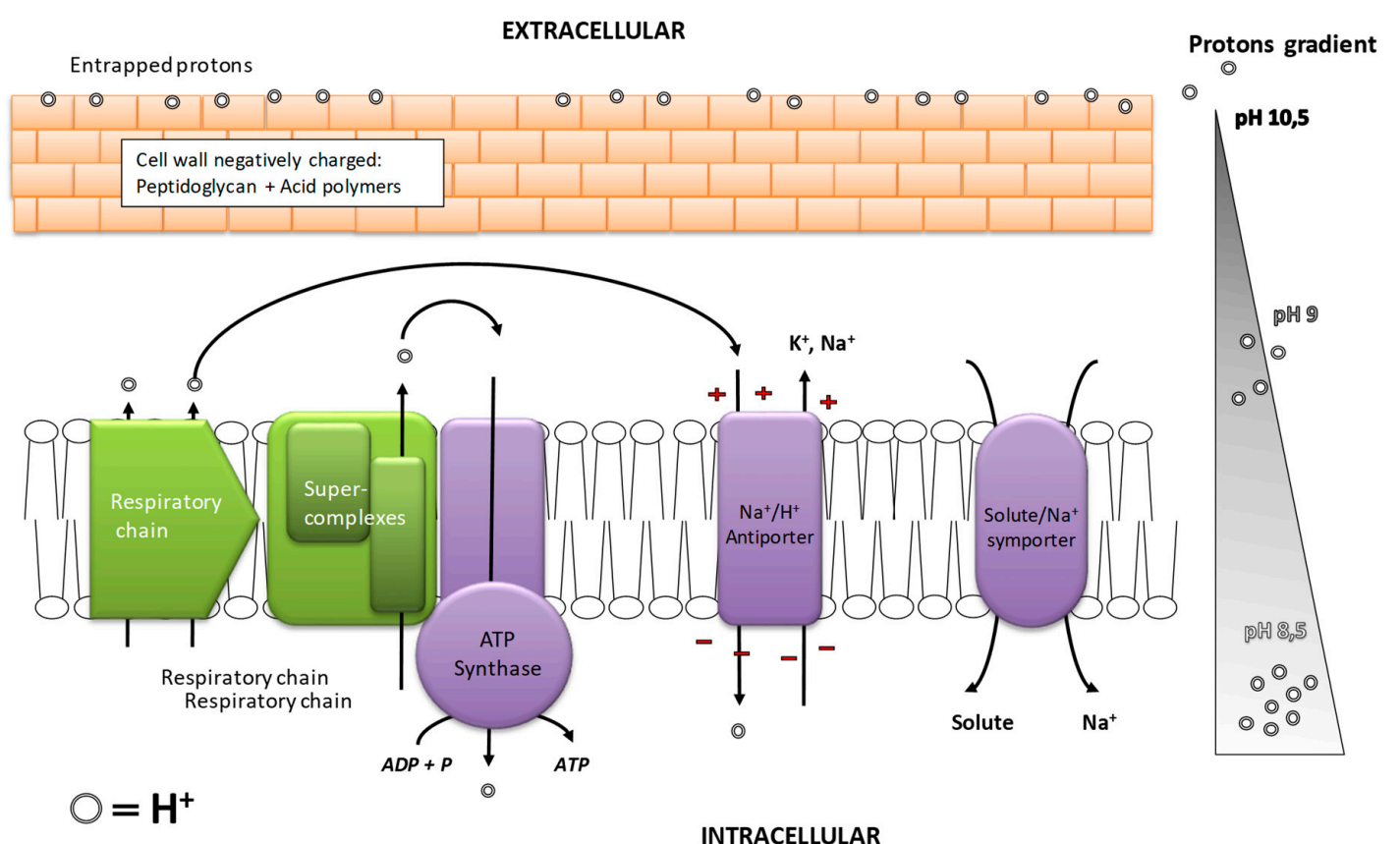

Figure 6. Protective mechanisms of Bacillus sp. cultivated at pH 10.5, adapted from after [111,117].

Therefore, bacteria also need to adapt to the alkalinization of their internal $\mathrm{pH}$ to maintain their activity. A major challenge would be to adapt the respiratory chain, which at neutral $\mathrm{pH}$ generates a proton gradient used for ATP synthesis or molecule transports. However, at alkaline $\mathrm{pH}$, the proton gradient is reversed. To maintain nutrient absorption, alkaliphilic bacteria use a gradient of $\mathrm{Na}^{+}$ ions. The sodium gradient created by membrane transporters replaces the proton gradient for the transport of nutrients (Figure 6). Thus, sodium is a key factor involved in the resistance to alkaline $\mathrm{pH}$. Adaptations related to the functioning of ATP-synthase have also been reported to counter-balance the low concentration of protons in the periplasm [117]. In the respiratory chain, enzymes group together into super-complexes to facilitate proton transport to ATP-synthase and improve promiscuity with ATP-synthase. The cytoplasmic membrane is organized into micro-domains that allow the respiratory chain and ATP-synthase to be compartmentalized and fixed nearby. Finally, ATP-synthase, itself, is modified to improve its affinity for protons [117].

Amino acid substitutions were also observed on various enzymes not necessarily involved in respiration, allowing them to operate efficiently at alkaline $\mathrm{pH}$ [119]. The optimal $\mathrm{pH}$ for proteins of alkaliphilic bacteria is, therefore, higher than those of neutrophilic bacteria. Horikoshi [111] highlighted an extracellular protease with an optimal $\mathrm{pH}$ of 11.5. This enzyme was able to maintain its protease activity up to $\mathrm{pH}$ 13.0. Amino acids sequence analyses of a protease [120], an amylase [121] and a phosphoserine aminotransferase of Bacillus sp. showed a common trend in amino acid substitutions. Negatively charged amino acids tended to be replaced by neutral amino acids. Amino acids such as lysine were replaced by arginine, which has a higher pKa. At the protein structural level, an increase in the number of hydrogen or hydrophobic bonds was observed [122].

These adaptation strategies have mostly been demonstrated from specific alkaliphilic bacterial species of the genus Bacillus. These bacteria are not necessarily denitrifying. However, there are alkaliphilic denitrifying bacteria, such as Halomonas desiderata, which have been isolated from a soda lake [123]. This species has shown an ability to grow and catalyze nitrate reduction in aqueous media from $\mathrm{pH} 10$ to $\mathrm{pH} 12$ [124-126]. It is likely that this type of alkaliphilic denitrifying bacteria would use the same mechanisms as described for the genus Bacillus.

\section{3. $\mathrm{pH}$ Threshold Values}

Surprisingly, one of the main difficulties when experimenting with alkaline bacterial cultures is to create and maintain a high $\mathrm{pH}$ in the culture medium [17]. The use of buffers such as phosphate 
and carbonate can be an option based on their high pKa: pKa $\left(\mathrm{HCO}_{3}{ }^{-} / \mathrm{CO}_{3}{ }^{2-}\right)=10.32$ and $\mathrm{pKa}$ $\left(\mathrm{HPO}_{4}{ }^{2-} / \mathrm{PO}_{4}{ }^{3}\right)=12.32$. Besides the medium limitation, it seems that there is a limit between $\mathrm{pH} 11.5$ and $\mathrm{pH} 12$ beyond which the physiology of bacterial cells is no longer possible. Many alkaliphilic bacteria already have their cellular activity significantly slowed down above $\mathrm{pH} 11$ [112,123,124]. For instance, several studies have compared bacterial reduction kinetics for $\mathrm{pH}$ values of 10,11 and 12 [53,54]. A first study tested the reduction of Cr (IV) [53] with Lake Mono sediments (California, USA), a second tested the reduction of nitrate with Buxton sediments [54]. In both studies, the activity was slowed at $\mathrm{pH} 11$ and no activity was observed at $\mathrm{pH}$ 12. In contrast, other works reported bacterial survival for $\mathrm{pH} 12$ or even higher [114,124,127]. However, as stated by Sorokin, particular attention must be paid to the operating conditions and a critical eye kept on what is reported [17]: (i) the $\mathrm{pH}$ of the culture is sometimes not maintained during the experiment or even not indicated, (ii) the $\mathrm{pH}$ reported in the feed medium is likely to be different from the culture $\mathrm{pH}$ in contact with bacteria. For example, alkaliphilic bacteria isolated from an alkaline lake were cultivated at a $\mathrm{pH}$ adjusted to very high values (up to 13.2) [116]. But the $\mathrm{pH}$ decreased over time and bacterial growth was only observed when the $\mathrm{pH}$ had decreased below 12.0. In another experiment, the authors correctly indicated a difference of $2 \mathrm{pH}$ units between the alkaline $\mathrm{pH}$ in the feeding medium and the $\mathrm{pH}$ in the culture [66].

\section{Perspectives, Denitrification at Alkaline $\mathrm{pH}$, with High Nitrate Concentration and with Hydrogen as Electron Source}

The impact of the association of high nitrate concentrations and alkaline $\mathrm{pH}$ on bacterial denitrification has not been well studied, especially with hydrogen as an energy source. Yet there is a strong interest in industrial perspectives, for nuclear waste repository management for instance [128,129]. In Figure 7, the different nitrate concentrations and $\mathrm{pH}$ investigated in the literature are summed up. It brings to light an important lack of knowledge concerning denitrifying cultures at high $\mathrm{pH}$ and high nitrate concentrations. In particular, there are no studies that have simultaneously tested a $\mathrm{pH}$ above 9 and a nitrate concentration above $120 \mathrm{mM}$. Therefore, future exploratory experiments conducted at high $\mathrm{pH}$ and high nitrate concentration should bring appreciable knowledge.

Despite the lack of experiments at high $\mathrm{pH}$ and high nitrate concentrations, speculations can be made about the behaviour of bacteria in this type of environment, based on the paragraphs above. Concentrations of the order of $100 \mathrm{mM}$ and $\mathrm{pH}$ values above 9.5 are likely to cause nitrite accumulations (up to $100 \%$ of the initial nitrate concentration). Particular attention should be paid to monitoring nitrite as it is likely to inhibit bacterial activity at low concentrations (tens of $\mathrm{mM}$ ). Moreover, while testing high nitrate concentrations, attention must be paid to the counter ion added with the nitrate as it could affect both $\mathrm{pH}$ and nitrate resistance. When testing alkaline $\mathrm{pH}$, the $\mathrm{pH}$ must be buffered and must be closely monitored as denitrifying activity modifies the $\mathrm{pH}$. Carbonates could be used as a buffer at alkaline $\mathrm{pH}$, especially since they provide a mineral carbon source for bacteria in hydrogenotrophy. It seems unlikely that hydrogenotrophic denitrifying bacteria would be active at $\mathrm{pH}>11$, as the alkalinization concomitant with their activity would quickly raise the $\mathrm{pH}$ to the threshold around 11.5 to 12 . 


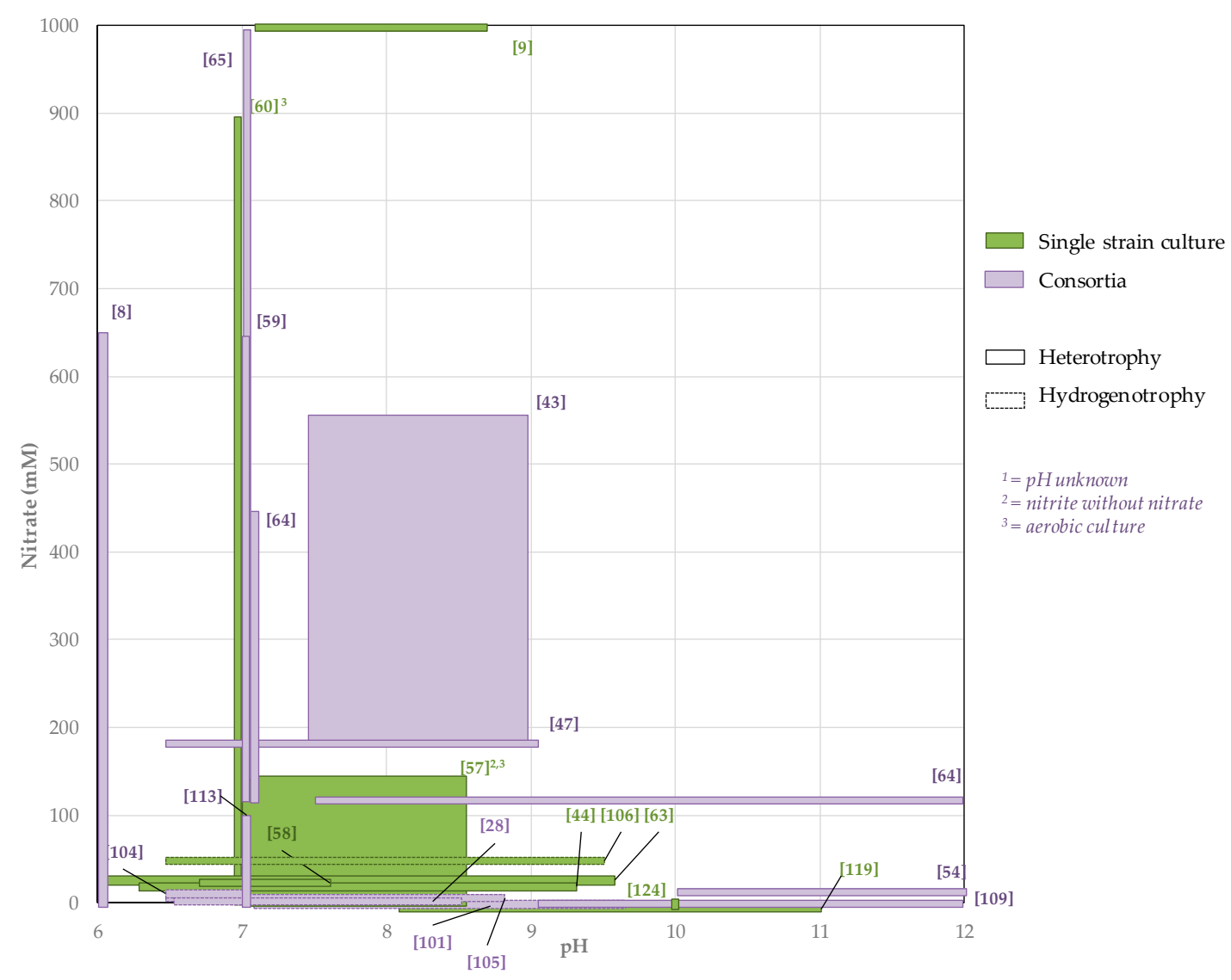

Figure 7. Literature overview of the experiments of bacterial denitrification conducted at alkaline $\mathrm{pH}$ and/or at high nitrate concentrations.

\section{Conclusions}

Exploring microbial denitrification in environments associated with alkaline $\mathrm{pH}$, high nitrate concentration and hydrogen as electron donor seems possible at $\mathrm{pH}$ up to 11 and nitrate concentrations up to hundreds of $\mathrm{mM}$. However, there is a lack of research associating these conditions and the potential negative effects of the three have generally been studied separately.

The maximal nitrate concentrations tested in the literature are generally about a few hundred $\mathrm{mM}$ of nitrate. At these concentrations, nitrite accumulation can reach $100 \%$ of the initial nitrate concentration. Nitrite is generally described as cytotoxic for bacterial cells at low concentrations (tens of $\mathrm{mM}$ ). Some authors have succeeded in cultivating bacterial strains in culture media containing $1 \mathrm{M}$ of nitrate. The counter ion added with nitrate, and more generally the salinity of the solution, is a major factor affecting the survival of bacteria. Some bacteria are tolerant to high salinities while others are inhibited by high concentrations of sodium. In addition, in a consortium, the composition of the bacterial population is decisive in the nitrite/nitrate balance.

In hydrogenotrophic cultures, denitrification and cell growth kinetics are generally slower than in heterotrophic cultures. One explanation is the availability of hydrogen, which is poorly soluble in aqueous media. The obligation for hydrogenotrophic bacteria to assimilate mineral carbon for growth is also a limiting factor. In addition, hydrogenotrophic denitrification appears to be more sensitive to high $\mathrm{pH}$ and more likely to cause nitrite accumulation than heterotrophic denitrification.

The $\mathrm{pH}$ is a determining factor for the survival of bacteria, the maximum limit values, below which microbial activity is possible, being between $\mathrm{pH} 11.5$ and 12 . The reduction of nitrite to nitric oxide generates alkalinity and, as a result, nitrite is likely to accumulate at alkaline $\mathrm{pH}$. For most bacteria, denitrification is therefore incomplete for $\mathrm{pH}>9.5$, nitrite accumulation is observed, and reductions kinetics are slowed down. The whole denitrification process has an opposite impact on the 
$\mathrm{pH}$ if the electron donor is organic or hydrogen. Heterotrophic bacteria are able to acidify the $\mathrm{pH}$ when the initial $\mathrm{pH}$ is high, while hydrogenotrophic bacteria only alkalinize the $\mathrm{pH}$. This crucial difference explains why hydrogenotrophic bacteria are more sensitive to alkaline $\mathrm{pH}$.

Author Contributions: Conceptualization, P.A. and N.D.; validation, B.E., A.B., J.-C.R. and A.A.; resources J.-C.R.; writing—original draft preparation, P.A.; writing—review and editing, P.A., B.E., A.B., and A.A.; supervision, B.E.; project administration, A.B.; funding acquisition, A.B.

Funding: This work was funded by the Andra (Agence nationale pour la gestion des déchets radioactifs) and the University of Toulouse

Conflicts of Interest: The authors declare that the research was conducted in the absence of any commercial or financial relationships that could be construed as a potential conflict of interest.

\section{Abbreviations}

FNR Fumarate and Nitrate reductase Regulatory (also NarR, NnrR and FnrP)

UQ Ubiquinone

$\mathrm{NAD}^{+} \quad$ Nicotinamide adenine dinucleotide

$\mathrm{FAD}^{+} \quad$ Flavin adenine dinucleotide

ATP Adenosine triphosphate

Cyt. c Cytochrome c

Nar Nitrate reductase (NarGHI, NapAB and NasA are also different nitrate reductases)

Nir Nitrite reductase (NirS and NiK are different nitrite reductases)

Nor Nitric oxide reductase

Nos Nitrous oxide reductase

\section{References}

1. Mohsenipour, M.; Shahid, S.; Ebrahimi, K. Removal techniques of nitrate from water. Asian J. Chem. 2014, 26, 7881-7886. [CrossRef]

2. Kapoor, A.; Viraraghavan, T. Nitrate Removal from Drinking Water-Review. J. Environ. Eng. 1997, 123, 371-380. [CrossRef]

3. Francis, C.W.; Hatcher, C.W. Biological Denitrification of High-Nitrates Wastes Generated in the Nuclear Industry; Environmental Sciences Division, Oak Ridge National Laboratory: Oak Ridge, TN, USA, 1980.

4. Albrecht, A.; Bertron, A.; Libert, M. Microbial Catalysis of Redox Reactions in Concrete Cells of Nuclear Waste Repositories: A Review and Introduction. In Cement-Based Materials for Nuclear Waste Storage; Springer: New York, NY, USA, 2013; pp. 147-159.

5. Stroes-Gascoyne, S.; Sergeant, C.; Schippers, A.; Hamon, C.J.; Nèble, S.; Vesvres, M.-H.; Barsotti, V.; Poulain, S.; Le Marrec, C. Biogeochemical processes in a clay formation in situ experiment: Part D-Microbial analyses-Synthesis of results. Appl. Geochem. 2011, 26, 980-989. [CrossRef]

6. Fernández-Nava, J.; Marañón, E.; Soons, J.; Castrillón, L. Denitrification of wastewater containing high nitrate and calcium concentrations. Bioresour. Technol. 2008, 99, 7976-7981. [CrossRef]

7. Marecik, R.; Biegańska-Marecik, R.; Cyplik, P.; Ławniczak, Ł.; Chrzanowski, Ł. Phytoremediation of Industrial Wastewater Containing Nitrates, Nitroglycerin, and Nitroglycol. Pol. J. Environ. Stud. 2013, 22, 773-780.

8. Napier, J.; Bustamante, R.B. In-Situ biodenitrification of the S-3 ponds. Environ. Prog. 1988, 7, 13-16. [CrossRef]

9. Denariaz, G.; Payne, W.J.; Gall, J.L.E. A Halophilic Denitrifier, Bacillus halodenitrificans sp. nov. Int. J. Syst. Bacteriol. 1989, 39, 145-151. [CrossRef]

10. Yarbrough, J.M.; Rake, J.B.; Eagon, R.G. Bacterial Inhibitory Effects of Nitrite: Inhibition of Active Transport, But Not of Group Translocation, and of Intracellular Enzymes. Appl. Environ. Microbiol. 1980, 39, 831-834.

11. Cua, L.S.; Stein, L.Y. Effects of nitrite on ammonia-oxidizing activity and gene regulation in three ammonia-oxidizing bacteria. FEMS Microbiol. Lett. 2011, 319, 169-175. [CrossRef]

12. Custer, M.C.; Hansen, J.N. Lactoferrin and Transferrin Fragments React with Nitrite to form an Inhibitor of Bacillus cereus Spore Outgrowth. Appl. Environ. Microbiol. 1983, 45, 942-949.

13. Park, H.I.; Choi, Y.J.; Pak, D. Autohydrogenotrophic denitrifying microbial community in a glass beads biofilm reactor. Biotechnol. Lett. 2005, 27, 949-953. [CrossRef] [PubMed] 
14. Bai, J.; Zhao, Q.; Wang, J.; Lu, Q.; Ye, X.; Gao, Z. Denitrification potential of marsh soils in two natural saline-alkaline wetlands. Chin. Geogr. Sci. 2014, 24, 279-286. [CrossRef]

15. Simek, M.; Cooper, J.E. The influence of soil $\mathrm{pH}$ on denitrification: Progress towards the understanding of this interaction over the last 50 years. Eur. J. Soil Sci. 2002, 345-354. [CrossRef]

16. Ruiz-Romero, E.; Alcántara-Hernández, R.; Cruz-Mondragon, C.; Marsch, R.; Luna-Guido, M.L.; Dendooven, L. Denitrification in extreme alkaline saline soils of the former lake Texcoco. Plant Soil 2009, 319, 247-257. [CrossRef]

17. Sorokin, D.Y. Is there a limit for high-pH life? Int. J. Syst. Evol. Microbiol. 2005, 55, 1405-1406. [CrossRef]

18. Gales, G.; Libert, M.-F.; Sellier, R.; Cournac, L.; Chapon, V.; Heulin, T. Molecular hydrogen from water radiolysis as an energy source for bacterial growth in a basin containing irradiating waste. FEMS Microbiol. Lett. 2004, 240, 155-162. [CrossRef]

19. Libert, M.; Bildstein, O.; Esnault, L.; Jullien, M.; Sellier, R. Molecular hydrogen: An abundant energy source for bacterial activity in nuclear waste repositories. Phys. Chem. Earth 2011, 36, 1616-1623. [CrossRef]

20. Grebliunas, B.D.; Perry, W.L. Carbon limitation of sediment bacterial production and denitrification in high nitrate low carbon systems. Environ. Earth Sci. 2016, 75, 662. [CrossRef]

21. Pedersen, K. Microbial life in deep granitic rock. FEMS Microbiol. Rev. 1997, 20, 399-414. [CrossRef]

22. Devlin, J.F.; Eedy, R.; Butler, B.J. The effects of electron donor and granular iron on nitrate transformation rates in sediments from a municipal water supply aquifer. J. Contam. Hydrol. 2000, 46, 81-97. [CrossRef]

23. Karanasios, K.A.; Vasiliadou, I.A.; Pavlou, S.; Vayenas, D. V Hydrogenotrophic denitrification of potable water: A review. J. Hazard. Mater. 2010, 180, 20-37. [CrossRef] [PubMed]

24. Mateju, V.; Krejci, J.; Janoch, T. Biological water denitrification-A review. Enzym. Microb. Technol. 1992, 14, 170-183. [CrossRef]

25. Ergas, S.J.; Reuss, A.F. Hydrogenotrophic denitrification of drinking water using a hollow fibre membrane bioreactor. J. Water Supply 2001, 50, 161-171. [CrossRef]

26. Liu, F.; Huang, G.; Fallowfield, H.; Guan, H.; Zhu, L.; Hu, H. Study on Heterotrophic-Autotrophic Denitrification Permeable Reactive Barriers (HAD PRBs) for In Situ Groundwater Remediation; Springer Briefs in Water Science and Technology; Springer: Berlin/Heidelberg, Germany, 2014; ISBN 978-3-642-38153-9.

27. Chang, C.C.; Tseng, S.K.; Huang, H.K. Hydrogenotrophic denitrification with immobilized Alcaligenes eutrophus for drinking water treatment. Bioresour. Technol. 1999, 69, 53-58. [CrossRef]

28. Ghafari, S.; Hasan, M.; Aroua, M.K. Improvement of autohydrogenotrophic nitrite reduction rate through optimization of $\mathrm{pH}$ and sodium bicarbonate dose in batch experiments. J. Biosci. Bioeng. 2009, 107, 275-280. [CrossRef]

29. Pelmont, J. Biodégradations et Métabolismes: Les Bactéries pour les Technologies de l'Environnement; EDP Sciences: Les Ulis, France, 2005; ISBN 286883745X.

30. Chen, J.; Strous, M. Denitrification and aerobic respiration, hybrid electron transport chains and co-evolution. Biochim. Biophys. Acta-Bioenerg. 2013, 1827, 136-144. [CrossRef]

31. van Spanning, R.J.M.; Richardson, D.J. Introduction to the Biochemistry and Molecular Biology of Denitrification. Biol. Nitrogen Cycle 2007, 3-20. [CrossRef]

32. Kučera, I.; Křivánková, L.; Dadák, V. The role of ubiquinone in linking nitrate reductase and cytochrome o to the respiratory chain of Paracoccus denitrificans. Biochim. Biophys. Acta-Bioenerg. 1984, 765, $43-47$. [CrossRef]

33. Richardson, D.J.; van Spanning, R.J.M. The Prokaryotic Nitrate Reductases. Biol. Nitrogen Cycle 2007, 21-35. [CrossRef]

34. Rinaldo, S.; Cutruzzolà, F. Nitrite Reductases in Denitrification. Biol. Nitrogen Cycle 2007, 37-55. [CrossRef]

35. Suharti de Vries, S.; Pouvreau, L.A.M. Nitric Oxide Reductase: Structural Variations and Catalytic Mechanism. Biol. Nitrogen Cycle 2007, 57-66. [CrossRef]

36. Zumft, W.G.; Körner, H. Nitrous Oxide Reductases. Biol. Nitrogen Cycle 2007, 67-81. [CrossRef]

37. Crack, J.C.; Hutchings, M.I.; Thomson, A.J.; Le, N.E. Biochemical properties of Paracoccus denitrificans FnrP: Reactions with molecular oxygen and nitric oxide. JBIC J. Biol. Inorg. Chem. 2016, 21, 71-82. [CrossRef] [PubMed]

38. Rinaldo, S.; Arcovito, A.; Giardina, G.; Castiglione, N.; Brunori, M.; Cutruzzolà, F. New insights into the activity of Pseudomonas aeruginosa cd 1 nitrite reductase. Biochem. Soc. Trans. 2008, 36, 1155-1159. [CrossRef] 
39. Giardina, G.; Rinaldo, S.; Johnson, K.A.; Di Matteo, A.; Brunori, M.; Cutruzzolà, F. NO sensing in Pseudomonas aeruginosa: Structure of the Transcriptional Regulator DNR. J. Mol. Biol. 2008, 378, 1002-1015. [CrossRef]

40. Rinaldo, S.; Giardina, G.; Brunori, M.; Cutruzzolà, F. N-oxide sensing in Pseudomonas aeruginosa: Expression and preliminary characterization of DNR, an FNR-CRP type transcriptional regulator. Biochem. Soc. Trans. 2005, 33, 184-186. [CrossRef]

41. Kuroki, M.; Igarashi, Y.; Ishii, M.; Arai, H. Fine-tuned regulation of the dissimilatory nitrite reductase gene by oxygen and nitric oxide in Pseudomonas aeruginosa. Environ. Microbiol. Rep. 2014, 6, 792-801. [CrossRef]

42. Kornaros, M.; Zafiri, C.; Lyberatos, G. Kinetics of denitrification by Pseudomonas denitrificans under growth conditions limited by carbon and/or nitrate or nitrite. Water Environ. Res. 1996, 68, 934-945. [CrossRef]

43. Thomsen, J.K.; Geest, T.; Cox, R.P. Mass Spectrometric Studies of the Effect of pH on the Accumulation of Intermediates in Denitrification by Paracoccus denitrificans. Appl. Environ. Microbiol. 1994, 536-541.

44. Kucera, I.; Dadak, V.; Matyasek, R. The influence of $\mathrm{pH}$ on the kinetics of dissimilatory nitrite reduction in Paracoccus denitrificans. Biochim. Biophys. Acta 1986, 848, 1-7. [CrossRef]

45. Van Rijn, J.; Tal, Y.; Barak, Y. Influence of volatile fatty acids on nitrite accumulation by a Pseudomonas stutzeri strain isolated from a denitrifying fluidized bed reactor. Appl. Environ. Microbiol. 1996, 62, 2615-2620. [PubMed]

46. Li, G.; Vilcherrez, D.; Carvajal-arroyo, J.M.; Sierra-alvarez, R.; Field, J.A. Exogenous nitrate attenuates nitrite toxicity to anaerobic ammonium oxidizing (anammox) bacteria. Chemosphere 2016, 144, 2360-2367. [CrossRef] [PubMed]

47. Glass, C.C.; Silverstein, J. Denitrification Kinetics of High Nitrate Concentration Water: $\mathrm{pH}$ Effect on Inhibition and Nitrite Accumulation. Water Res. 1998, 32, 831-839. [CrossRef]

48. Wilderer, P.A.; Jones, W.L.; Daub, U. Competition in denitrification systems affecting reduction rate and accumulation of nitrite. Water Res. 1987, 21, 239-245. [CrossRef]

49. Liessens, J.; Vanbrabant, J.; De Vos, P.; Kersters, K.; Verstraete, W. Mixed culture hydrogenotrophic nitrate reduction in drinking water. Microb. Ecol. 1992, 24, 271-290. [CrossRef]

50. Szekeres, S.; Kiss, I.; Kalman, M.; Soares, M.I.M. Microbial population in a hydrogen-dependent denitrification reactor. Water Res. 2002, 36, 4088-4094. [CrossRef]

51. Turk, O.; Mavinic, D.S. Benefits of using selective inhibition to remove nitrogen from highly nitrogenous wastes. Environ. Technol. Lett. 1987, 8, 419-426. [CrossRef]

52. Bollag, J.-M.; Henninger, N.M. Effects of nitrite toxicity on soil bacteria aerobic and anaerobic conditions. Soil Biol. Biochem. 1978, 10, 377-381. [CrossRef]

53. Watts, M.P.; Khijniak, T.V.; Boothman, C.; Lloyd, J.R. Treatment of alkaline Cr(VI)-contaminated leachate with an alkaliphilic metal-reducing bacterium. Appl. Environ. Microbiol. 2015, 81, 5511-5518. [CrossRef]

54. Rizoulis, A.; Steele, H.M.; Morris, K.; Lloyd, J.R. The potential impact of anaerobic microbial metabolism during the geological disposal of intermediate-level waste. Environ. Sci. 2012, 76, 3261-3270. [CrossRef]

55. Banihani, Q.; Sierra-Alvarez, R.; Field, J.A. Nitrate and nitrite inhibition of methanogenesis during denitrification in granular biofilms and digested domestic sludges. Biodegradation 2009, 20, 801-812. [CrossRef] [PubMed]

56. Marais, J.P.; Therion, J.J.; Mackie, R.I. Effect of nitrate and its reduction products on the growth and activity of the rumen microbial population. Br. J. Nutr. 1988, 59, 301-313. [CrossRef] [PubMed]

57. Hartop, K.R.; Sullivan, M.J.; Giannopoulos, G.; Gates, A.J.; Bond, P.L.; Yuan, Z.; Clarke, T.A.; Rowley, G.; Richardson, D.J. The metabolic impact of extracellular nitrite on aerobic metabolism of Paracoccus denitrificans. Water Res. 2017, 113, 207-214. [CrossRef] [PubMed]

58. Baumann, B.; van der Meer, J.R.; Snozzi, M.; Zehnder, A.J. Inhibition of denitrification activity but not of mRNA induction in Paracoccus denitrificans by nitrite at a suboptimal pH. Antonie Van Leeuwenhoek 1997, 72, 183-189. [CrossRef] [PubMed]

59. Dhamole, P.B.; Nair, R.R.; Souza, S.F.D.; Lele, S.S. Denitrification of high strength nitrate waste. Bioresour. Technol. 2007, 98, 247-252. [CrossRef]

60. Blasco, R.; Martínez-Luque, M.; Madrid, M.P.; Castillo, F.; Moreno-Vivián, C. Rhodococcus sp. RB1 grows in the presence of high nitrate and nitrite concentrations and assimilates nitrate in moderately saline environments. Arch. Microbiol. 2001, 175, 435-440. [CrossRef]

61. Mariángel, L.; Aspé, E.; Martí, M.C.; Roeckel, M. The effect of sodium chloride on the denitrification of saline fishery wastewaters. Environ. Technol. 2008, 29, 871-879. [CrossRef] 
62. Dinçer, A.R.; Kargi, F. Salt Inhibition of Nitrification and Denitrification in Saline Wastewater. Environ. Technol. 1999, 20, 1147-1153. [CrossRef]

63. Glass, C.; Silverstein, J. Denitrification of high-nitrate, high-salinity wastewater. Water Res. 1999, 33, $223-229$. [CrossRef]

64. Miao, Y.; Liao, R.; Zhang, X.X.; Liu, B.; Li, Y.; Wu, B.; Li, A. Metagenomic insights into salinity effect on diversity and abundance of denitrifying bacteria and genes in an expanded granular sludge bed reactor treating high-nitrate wastewater. Chem. Eng. J. 2015, 277, 116-123. [CrossRef]

65. Liao, R.; Shen, K.; Li, A.-M.; Shi, P.; Li, Y.; Shi, Q.; Wang, Z. High-nitrate wastewater treatment in an expanded granular sludge bed reactor and microbial diversity using 454 pyrosequencing analysis. Bioresour. Technol. 2013, 134, 190-197. [CrossRef] [PubMed]

66. Dhamole, P.B.; Nair, R.R.; Lele, S.S. Denitrification of Highly Alkaline Nitrate Waste Using Adapted Sludge. Appl. Biochem. Biotechnol. 2008, 151, 433-440. [CrossRef] [PubMed]

67. Heimann, A.; Jakobsen, R.; Blodau, C. Energetic Constraints on $\mathrm{H}_{2}$-Dependent Terminal Electron Accepting Processes in Anoxic Environments: A Review of Observations and Model Approaches. Environ. Sci. Technol. 2010, 44, 24-33. [CrossRef] [PubMed]

68. Schwartz, E.; Fritsch, J.; Friedrich, B. $\mathrm{H}_{2}$-Metabolizing Prokaryotes. In The Prokaryotes; Springer: Berlin/Heidelberg, Germany, 2013; pp. 119-199.

69. Burgdorf, T.; Lenz, O.; Buhrke, T.; van der Linden, E.; Jones, A.K.; Albracht, S.P.J.; Friedrich, B. [NiFe]-hydrogenases of Ralstonia eutropha H16: Modular enzymes for oxygen-tolerant biological hydrogen oxidation. J. Mol. Microbiol. Biotechnol. 2005, 10, 181-196. [CrossRef]

70. Winkler, M.; Esselborn, J.; Happe, T. Molecular basis of [FeFe]-hydrogenase function: An insight into the complex interplay between protein and catalytic cofactor. Biochim. Biophys. Acta-Bioenerg. 2013, 1827, 974-985. [CrossRef]

71. Horch, M.; Lauterbach, L.; Lenz, O.; Hildebrandt, P.; Zebger, I. NAD(H)-coupled hydrogen cycling-structure-function relationships of bidirectional [NiFe] hydrogenases. FEBS Lett. 2012, 586, 545-556. [CrossRef]

72. Seigo, S.; Oliver, P.; Sonja, V.; Michael, S.; Stagni, M.S. The Crystal Structure of [Fe]-Hydrogenase Reveals the Geometry of the Active Site. Science 2008, 321, 572-576.

73. Laska, S.; Kletzin, A. Improved purification of the membrane-bound hydrogenase-sulfur-reductase complex from thermophilic archaea using $\epsilon$-aminocaproic acid-containing chromatography buffers. J. Chromatogr. $B$ Biomed. Sci. Appl. 2000, 737, 151-160. [CrossRef]

74. Korbas, M.; Vogt, S.; Meyer-Klaucke, W.; Bill, E.; Lyon, E.J.; Thauer, R.K.; Shima, S. The iron-sulfur cluster-free hydrogenase (Hmd) is a metalloenzyme with a novel iron binding motif. J. Biol. Chem. 2006, 281, 30804-30813. [CrossRef]

75. Lim, J.K.; Kang, S.G.; Lebedinsky, A.V.; Lee, J.-H.; Lee, H.S. Identification of a Novel Class of Membrane-Bound [NiFe]-Hydrogenases in Thermococcus onnurineus NA1 by In Silico Analysis. Appl. Environ. Microbiol. 2010, 76, 6286-6289. [CrossRef]

76. Liot, Q.; Constant, P. Breathing air to save energy-New insights into the ecophysiological role of high-affinity [NiFe]-hydrogenase in Streptomyces avermitilis. Microbiologyopen 2016, 5, 47-59. [CrossRef] [PubMed]

77. Infossi, P.; Lojou, E.; Chauvin, J.-P.; Herbette, G.; Brugna, M.; Giudici-Orticoni, M.-T. Aquifex aeolicus membrane hydrogenase for hydrogen biooxidation: Role of lipids and physiological partners in enzyme stability and activity. Int. J. Hydrog. Energy 2010, 35, 10778-10789. [CrossRef]

78. Islam, Z.F.; Cordero, P.R.F.; Feng, J.; Chen, Y.-J.; Bay, S.K.; Jirapanjawat, T.; Gleadow, R.M.; Carere, C.R.; Stott, M.B.; Chiri, E.; et al. Two Chloroflexi classes independently evolved the ability to persist on atmospheric hydrogen and carbon monoxide. ISME J. 2019, 13, 1801-1813. [CrossRef] [PubMed]

79. Cassier-Chauvat, C.; Veaudor, T.; Chauvat, F. Advances in the function and regulation of hydrogenase in the cyanobacterium Synechocystis PCC6803. Int. J. Mol. Sci. 2014, 15, 19938-19951. [CrossRef]

80. Mei, N.; Postec, A.; Monnin, C.; Pelletier, B.; Payri, C.E.; Ménez, B.; Frouin, E.; Ollivier, B.; Erauso, G.; Quéméneur, M. Metagenomic and PCR-Based Diversity Surveys of [FeFe]-Hydrogenases Combined with Isolation of Alkaliphilic Hydrogen-Producing Bacteria from the Serpentinite-Hosted Prony Hydrothermal Field, New Caledonia. Front. Microbiol. 2016, 7, 1301. [CrossRef] 
81. Acta, B.; Bba, P.; Fondamentale, R.; Associd, L.; No, C.; Nucleaires, E. Comparison of the membrane-bound and detergent-solubilised hydrogenase from paracoccus denitrificans isolation of the hydrogenase. Biochim. Biophys. Acta-Enzymol. 1979, 570, 43-55.

82. Knuttel, K.; Schneider, K.; Schlegel, H.G.; Muller, A. The membrane-bound hydrogenase from Paracoccus denitrificans. Purification and molecular characterization. Eur. J. Biochem. 1989, 179, 101-108. [CrossRef]

83. Mao, Y.; Xia, Y.; Wang, Z.; Zhang, T. Reconstructing a Thauera genome from a hydrogenotrophic-denitrifying consortium using metagenomic sequence data. Appl. Microbiol. Biotechnol. 2014, 98, 6885-6895. [CrossRef]

84. Zhang, Y.; Zhong, F.; Xia, S.; Wang, X.; Li, J. Autohydrogenotrophic denitrification of drinking water using a polyvinyl chloride hollow fiber membrane biofilm reactor. J. Hazard. Mater. 2009, 170, 203-209. [CrossRef]

85. Yoon, J.-H.; Kang, S.-J.; Ryu, S.H.; Jeon, C.O.; Oh, T.-K. Hydrogenophaga bisanensis sp. nov., isolated from wastewater of a textile dye works. Int. J. Syst. Evol. Microbiol. 2008, 58, 393-397. [CrossRef]

86. Sargent, F. The Model [NiFe]-Hydrogenases of Escherichia coli. In Advances in Microbial Physiology; Academic Press: London, UK, 2016; Volume 68, pp. 433-507.

87. Schäfer, C.; Friedrich, B.; Lenz, O. Novel, oxygen-insensitive group 5 [NiFe]-hydrogenase in Ralstonia eutropha. Appl. Environ. Microbiol. 2013, 79, 5137-5145. [CrossRef] [PubMed]

88. Rey, F.E.; Oda, Y.; Harwood, C.S. Regulation of uptake hydrogenase and effects of hydrogen utilization on gene expression in Rhodopseudomonas palustris. J. Bacteriol. 2006, 188, 6143-6152. [CrossRef] [PubMed]

89. Schut, G.J.; Adams, M.W.W. The iron-hydrogenase of Thermotoga maritima utilizes ferredoxin and NADH synergistically: A new perspective on anaerobic hydrogen production. J. Bacteriol. 2009, 191, 4451-4457. [CrossRef] [PubMed]

90. Ballor, N.R.; Paulsen, I.; Leadbetter, J.R. Genomic Analysis Reveals Multiple [FeFe] Hydrogenases and Hydrogen Sensors Encoded by Treponemes from the H2-Rich Termite Gut. Microb. Ecol. 2012, 63, 282-294. [CrossRef]

91. Ash, P.A.; Liu, J.; Coutard, N.; Heidary, N.; Horch, M.; Gudim, I.; Simler, T.; Zebger, I.; Lenz, O.; Vincent, K.A. Electrochemical and Infrared Spectroscopic Studies Provide Insight into Reactions of the NiFe Regulatory Hydrogenase from Ralstonia eutropha with $\mathrm{O}_{2}$ and CO. J. Phys. Chem. B 2015, 119, 13807-13815. [CrossRef]

92. Burgdorf, T.; De Lacey, A.L.; Friedrich, B. Functional analysis by site-directed mutagenesis of the NAD(+)-reducing hydrogenase from Ralstonia eutropha. J. Bacteriol. 2002, 184, 6280-6288. [CrossRef]

93. Nesbit, A.D.; Fleischhacker, A.S.; Teter, S.J.; Kiley, P.J. ArcA and AppY antagonize IscR repression of hydrogenase-1 expression under anaerobic conditions, revealing a novel mode of $\mathrm{O}_{2}$ regulation of gene expression in Escherichia coli. J. Bacteriol. 2012, 194, 6892-6899. [CrossRef]

94. Dijkhuizen, L.; Harder, W. Current views on the regulation of autotrophic carbon dioxide fixation via the Calvin cycle in bacteria. J. Microbiol. 1984, 50, 473-487. [CrossRef]

95. Fuchs, G. Alternative Pathways of Carbon Dioxide Fixation: Insights into the Early Evolution of Life? Annu. Rev. Microbiol. 2011, 65, 631-658. [CrossRef]

96. Blombach, B.; Takors, R. $\mathrm{CO}_{2}$-intrinsic product, essential substrate, and regulatory trigger of microbial and mammalian production processes. Front. Bioeng. Biotechnol. 2015, 3, 108. [CrossRef]

97. Tong, L. Structure and function of biotin-dependent carboxylases. Cell. Mol. Life Sci. 2013, 70, 863-891. [CrossRef] [PubMed]

98. Chollet, R.; Vidal, J.; O'Leary, M.H. PhosphoEnolPyruvate Carboxylase: A Ubiquitous, Highly Regulated Enzyme in Plants. Annu. Rev. Plant Physiol. Plant Mol. Biol. 1996, 47, 273-298. [CrossRef] [PubMed]

99. Vasiliadou, I.A.; Siozios, S.; Papadas, I.T.; Bourtzis, K.; Pavlou, S.; Vayenas, D.V. Kinetics of pure cultures of hydrogen-oxidizing denitrifying bacteria and modeling of the interactions among them in mixed cultures. Biotechnol. Bioeng. 2006, 95, 513-525. [CrossRef] [PubMed]

100. Ghafari, S.; Hasan, M.; Aroua, M.K. Effect of carbon dioxide and bicarbonate as inorganic carbon sources on growth and adaptation of autohydrogenotrophic denitrifying bacteria. J. Hazard. Mater. 2009, 162, 1507-1513. [CrossRef]

101. Rezania, B.; Cicek, N.; Oleszkiewicz, J.A. Kinetics of Hydrogen-Dependent Denitrification Under Varying pH and Temperature Conditions. Biotechnol. Bioeng. 2005, 92, 900-906. [CrossRef]

102. Epsztein, R.; Beliavski, M.; Tarre, S.; Green, M. High-rate hydrogenotrophic denitrification in a pressurized reactor. Chem. Eng. J. 2016, 286, 578-584. [CrossRef] 
103. Lee, J.W.; Lee, K.H.; Park, K.Y.; Maeng, S.K. Bioresource Technology Hydrogenotrophic denitrification in a packed bed reactor: Effects of hydrogen-to-water flow rate ratio. Bioresour. Technol. 2010, 101, 3940-3946. [CrossRef]

104. Vasiliadou, I.A.; Pavlou, S.; Vayenas, D.V. A kinetic study of hydrogenotrophic denitrification. Process Biochem. 2006, 41, 1401-1408. [CrossRef]

105. Tang, Y.; Zhou, C.; Ziv-El, M.; Rittmann, B.E. A pH-control model for heterotrophic and hydrogen-based autotrophic denitrification. Water Res. 2011, 45, 232-240. [CrossRef]

106. Chih-Cheng, C.; Szu-Kung, T. The optimum condition for autotrophic denitrification by Paracoccus denitrificans. J. Chin. Inst. Environ. Eng. 1998, 8, 233-238.

107. Lee, K.-C.; Rittmann, B.E. Effects of $\mathrm{pH}$ and precipitation on autohydrogenotrophic denitrification using the hollow-fiber membrane-biofilm reactor. Water Res. 2003, 37, 1551-1556. [CrossRef]

108. Timmermans, P.; Van Haute, A. Denitrification with methanol Fundamental study of the growth and denitrification capacity of Hyphomicrobium sp. Water Res. 1983, 17, 1249-1255. [CrossRef]

109. Durban, N.; Rafrafi, Y.; Rizoulis, A.; Albrecht, A.; Robinet, J.-C.; Lloyd, J.R.; Bertron, A.; Erable, B. Nitrate and nitrite reduction at high $\mathrm{pH}$ in a cementitious environment by a microbial microcosm. Int. Biodeterior. Biodegrad. 2018, 134, 93-102. [CrossRef]

110. Blaszczyk, M. Effect of Medium Composition on the Denitrification of Nitrate by Paracoccus denitrificans. Appl. Environ. Microbiol. 1993, 59, 3951-3953. [PubMed]

111. Horikoshi, K. Alkaliphiles: Some Applications of Their Products for Biotechnology. Microbiol. Mol. Biol. Rev. $1999,63,735-750$.

112. Janto, B.; Ahmed, A.; Ito, M.; Liu, J.; Hicks, D.B.; Pagni, S.; Fackelmayer, O.J.; Smith, T.; Earl, J.; Elbourne, L.D.H.; et al. The genome of alkaliphilic Bacillus pseudofirmus OF4 reveals adaptations that support the ability to grow in an external $\mathrm{pH}$ range from 7.5 to 11.4. Environ. Microbiol. 2012, 13, 3289-3309. [CrossRef]

113. Thorpe, C.L.; Law, G.T.W.; Boothman, C.; Lloyd, J.R.; Burke, I.T.; Morris, K. The Synergistic Effects of High Nitrate Concentrations on Sediment Bioreduction. Geomicrobiol. J. 2012, 29, 484-493. [CrossRef]

114. Li, W.; Li, C.; Lin, X.; Liu, Y.; Abbas, G.; Zheng, P. Effects of operation mode on self-alkalization of high-load denitrifying reactor. Bioresour. Technol. 2015, 187, 282-287. [CrossRef]

115. Pedersen, K.; Nilsson, E.; Arlinger, J.; Hallbeck, L.; O'Neill, A. Distribution, diversity and activity of microorganisms in the hyper-alkaline spring waters of Maqarin in Jordan. Extremophiles 2004, 8, 151-164. [CrossRef]

116. Roadcap, G.S.; Sanford, R.A.; Jin, Q.; Pardinas, R.; Bethke, C.M. Extremely Alkaline (pH > 12) Ground Water Hosts Diverse Microbial Community. Ground Water 2006, 44, 511-517. [CrossRef]

117. Preiss, L.; Hicks, D.B.; Suzuki, S.; Meier, T.; Krulwich, T.A. Alkaliphilic bacteria with impact on industrial applications, concepts of early life forms, and bioenergetics of ATP synthesis. Front. Bioeng. Biotechnol. 2015, 3, 75. [CrossRef] [PubMed]

118. Sturr, M.G.; Guffanti, A.A.; Krulwich, T.A. Growth and Bioenergetics of Alkaliphilic Bacillus finmus OF4 in Continuous Culture at High pH. J. Bacteriol. Microbiol. 1994, 176, 3111-3116. [CrossRef] [PubMed]

119. Ling, H.L.; Rahmat, Z.; Bakar, F.D.A.; Murad, A.M.A.; Illias, R.M. Secretome analysis of alkaliphilic bacterium Bacillus lehensis G1 in response to $\mathrm{pH}$ changes. Microbiol. Res. 2018, 215, 46-54. [CrossRef] [PubMed]

120. Shirai, T.; Suzuki, A.; Yamane, T.; Ashida, T.; Kobayashi, T.; Hitomi, J.; Ito, S. High-resolution crystal structure of M-protease: Phylogeny aided analysis of the high-alkaline adaptation mechanism. Protein Eng. 1997, 10, 627-634. [CrossRef] [PubMed]

121. Shirai, T.; Igarashi, K.; Ozawa, T.; Hagihara, H.; Kobayashi, T.; Ozaki, K.; Ito, S. Ancestral Sequence Evolutionary Trace and Crystal Structure Analyses of Alkaline $\alpha$-Amylase from Bacillus sp. KSM-1378 to Clarify the Alkaline Adaptation Process of Proteins. Proteins Struct. Funct. Bioinform. 2007, 66, 600-610. [CrossRef]

122. Dubnovitsky, A.P.; Kapetaniou, E.G.; Papageorgiou, A.C. Enzyme adaptation to alkaline pH: Atomic resolution $(1.08 \AA)$ structure of phosphoserine aminotransferase from Bacillus alcalophilus. Protein Sci. 2005, 14, 97-110. [CrossRef]

123. Shapovalova, A.A.; Khijniak, T.V.; Tourova, T.P.; Muyzer, G.; Sorokin, D.Y. Heterotrophic denitrification at extremely high salt and $\mathrm{pH}$ by haloalkaliphilic Gammaproteobacteria from hypersaline soda lakes. Extremophiles 2008, 12, 619-625. [CrossRef] 
124. Rafrafi, Y.; Bertron, A.; Albrecht, A.; Erable, B. Surface and bacterial reduction of nitrate at alkaline $\mathrm{pH}$ : Conditions comparable to a nuclear waste repository. Int. Biodeterior. Biodegrad. 2015, 101, 12-22. [CrossRef]

125. Alquier, M.; Kassim, C.; Bertron, A.; Sablayrolles, C.; Rafrafi, Y.; Albrecht, A.; Erable, B. Halomonas desiderata as a bacterial model to predict the possible biological nitrate reduction in concrete cells of nuclear waste disposals. J. Environ. Manage. 2014, 132, 32-41. [CrossRef]

126. Rafrafi, Y.; Durban, N.; Bertron, A.; Albrecht, A.; Robinet, J.; Erable, B. Use of a continuous-flow bioreactor to evaluate nitrate reduction rate of Halomonas desiderata in cementitious environment relevant to nuclear waste deep repository. Biochem. Eng. J. 2017, 125, 161-170. [CrossRef]

127. Yoshida, T. Acetate biodegradation by anaerobic microorganisms at high $\mathrm{pH}$ and high calcium concentration. J. Environ. Radioact. 2011, 102, 170-177. [CrossRef] [PubMed]

128. Bertron, A.; Ranaivomanana, H.; Jacquemet, N.; Erable, B.; Sablayrolles, C.; Escadeillas, G.; Albrecht, A. Physico-chemical interactions at the concrete-bitumen interface of nuclear waste repositories. EPJ Web Conf. 2013, 56, 01002. [CrossRef]

129. Bertron, A. Understanding interactions between cementitious materials and microorganisms: a key to sustainable and safe concrete structures in various contexts. Mater. Struct. 2014, 47, 1787-1806. [CrossRef]

(C) 2019 by the authors. Licensee MDPI, Basel, Switzerland. This article is an open access article distributed under the terms and conditions of the Creative Commons Attribution (CC BY) license (http://creativecommons.org/licenses/by/4.0/). 